\title{
Defects in homologous recombination repair behind the human diseases: FA and HBOC
}

\section{Yoko Katsuki and Minoru Takata}

Laboratory of DNA Damage Signaling, Department of Late Effects Studies, Radiation Biology Center, Kyoto University, Yoshidakonoecho, Sakyo-ku, Kyoto, Japan

Correspondence should be addressed to M Takata Email mtakata@house.rbc.kyoto-u. ac.jp

\begin{abstract}
Hereditary breast and ovarian cancer (HBOC) syndrome and a rare childhood disorder Fanconi anemia (FA) are caused by homologous recombination (HR) defects, and some of the causative genes overlap. Recent studies in this field have led to the exciting development of PARP inhibitors as novel cancer therapeutics and have clarified important mechanisms underlying genome instability and tumor suppression in HR-defective disorders. In this review, we provide an overview of the basic molecular mechanisms governing HR and DNA crosslink repair, highlighting $B R C A 2$, and the intriguing relationship between $\mathrm{HBOC}$ and FA.
\end{abstract}

\author{
Key Words \\ - Fanconi anemia \\ - bRCA2 \\ - hereditary breast and \\ ovarian cancer \\ - interstrand crosslink \\ repair \\ - homologous \\ recombination
}

\section{Introduction}

Breast or ovarian cancer is common, and one of the leading causes of mortality in women worldwide (Ferlay et al. 2015, Torre et al. 2015). Although hereditary forms of breast and ovarian cancer (HBOC) are estimated to account for only $5-20 \%$ of all cases of breast or ovarian cancer (Nielsen \& van Overeem Hansen 2016), HBOC has been recently attracting considerable public attention in many parts of the world, including Japan. A fraction $(\sim 25 \%)$ of HBOC cases are caused by monoallelic, that is dominant, mutations in either the BRCA1 or BRCA2 genes (Nielsen \& van Overeem Hansen 2016), the wellknown tumor suppressors that were identified by linkage analysis in the mid-1990s (Miki et al. 1994, Wooster et al. 1995). The lifetime risk of developing breast or ovarian cancer can be up to $\sim 80 \%$ in these affected individuals. Mutations in BRCA1/2 also predispose individuals to cancer in other organs such as prostate or pancreas.
The BRCA genes are considered to be 'caretakers', and they function in homologous recombination (HR) repair, thereby protecting our genome from carcinogenic alterations. Furthermore, cancer genome sequences have revealed an unexpectedly high frequency of HR gene mutations in sporadic cases of high-grade serous ovarian cancer (Cancer Genome Atlas Research Network 2011), highlighting an important role of HR in cancer prevention via genome maintenance.

As the loss of HR activities by the biallelic disruption of either the Brca1 or Brca2 genes in mice results in early embryonic lethality (for example see Ludwig et al. 1997), it was a real surprise to the scientific community that the D'Andrea lab at Harvard University discovered biallelic mutations in BRCA2 in a subset of patients with the rare childhood hematological disorder, Fanconi anemia (FA) (FA-D1 subgroup) in 2002 (Howlett et al. 2002).

This paper forms part of a thematic review section on 20 Years of BRCA 1 and 2 . The Guest Editors for this section were Kokichi Sugano and William Foulkes. 
The combined effects of these biallelic BRCA2/FANCD1 mutations appear to be hypomorphic and somehow compatible with life.

FA is very rare, but still the most prevalent among the inherited forms of bone marrow failure syndrome (Auerbach 2009). It is primarily an autosomal recessive disorder that is clinically characterized by congenital malformations, progressive development of hypoplastic anemia and cancer predisposition that often results in hematological malignancies such as acute myelogenous leukemia (AML) or myelodysplasia (MDS) as well as various solid tumors, especially head and neck squamous carcinoma (Alter 2014). FA was first described in 1927 by the Swiss pediatrician Guido Fanconi (Lobitz \& Velleuer 2006). Traute Schroeder and coworkers reported spontaneous chromosomal breakage in FA in 1964 (Schroeder et al. 1964). Ten years later, Sasaki and Tonomura discovered that FA cells are extremely sensitive to ICL-inducing agents such as mitomycin C (MMC) (Sasaki \& Tonomura 1973), resulting from defective interstrand crosslink (ICL) repair. It is now generally accepted that an ICL is repaired through consecutive steps of multiple DNA repair activities including the HR mechanism (Fig. 1) (Duxin \& Walter 2015).

More recently, it has been recognized that mutation carriers of some of the FA genes (e.g., parents of the FA patients) may actually develop HBOC and that the other HBOC genes (i.e., BRCA1 (Domchek et al. 2013, Sawyer et al. 2015)) can cause an FA-like disorder when biallelically mutated (Bogliolo \& Surrallés 2015). Thus, HBOC and the FA genes do overlap to some extent (Tables 1 and 2). In a simplified view, it could be said that near-total loss of (or hypomorphic) HR repair activities causes the FA phenotype (or sometimes FA-like, see the 'The core HR genes in the FA pathway' section below), whereas breast and ovarian cancer without constitutive symptoms (i.e., HBOC) is caused when the HR repair activities are disabled to certain levels. However, HR is severely disabled in the HBOC tumors, by loss of heterozygosity (LOH), promoter methylation or other mechanisms. In this review, we provide a brief overview of the current understanding of the molecular mechanism of HR and ICL repairs, highlighting $B R C A 2$, and their relationship with two important human diseases, $\mathrm{HBOC}$ and FA.

\section{Genome integrity is maintained by DNA repair}

Each day, every cell incurs a large number of DNA lesions that threaten the integrity of the genome. These lesions originate either from an exogenous source (e.g., X-rays or ultraviolet light) or are created endogenously by metabolic pathways (i.e., free radicals or aldehydes) or by programmed cellular activities (i.e., VDJ recombination in developing lymphocytes or meiotic recombination in germ cells) (Hoeijmakers 2001). Alternatively, it is known that replication stress provoked by oncogene activation or fork collision with transcription machineries can induce stalled replication forks that may result in fork collapse in genomic regions such as common fragile sites (Debatisse et al. 2012).

A DNA double-strand break (DSB) is among the most severe insults to the genome, and it can be repaired by two basic mechanisms termed HR or nonhomologous end joining (NHEJ). HR and NHEJ function in a cooperative and overlapping manner, or perhaps paradoxically, can compete with each other (Takata et al. 1998, Prakash et al. 2015). Although NHEJ can function throughout the cell cycle, the HR pathway only functions during S/G2 phase. In essence, NHEJ unites two DNA ends by ligation without any requirement of homology, often after processing (i.e., removal or addition of short stretches of nucleotides) of the ends. Therefore, the repair process can be error-prone. On the other hand, HR functions by a 'copy-and-paste' mechanism of genetic information transfer from an intact homologous template to the damaged DNA, and therefore it occurs without sequence alteration. HR normally requires replicated DNA (sister chromatid) as a template, and this is one of the reasons for HR to be restricted to the $\mathrm{S}$ and $\mathrm{G} 2$ phases of the cell cycle.

In addition to their role in DSB repair, HR proteins have an important role during $S$ phase, where they function in restarting stalled replication forks or protecting stalled replication forks from collapsing due to nucleolytic digestion (Hashimoto et al. 2012, Schlacher et al. 2012). For example, loss of Rad51 in mice (Tsuzuki et al. 1996) or chicken DT40 cells (Sonoda et al. 1998) causes cell lethality, which is accompanied by chromosomal breaks likely due to replication fork collapse. HR is also an integral step during ICL repair, as illustrated in Fig. 1.

\section{Basic molecular mechanisms of HR repair}

The mechanisms of HR can be best explained in the context of DSB repair (Fig. 2). To initiate DSB repair through $\mathrm{HR}$, the DSB end needs to be nucleolytically resected to generate 3' single-stranded DNA (ssDNA). This is quickly coated by the trimeric ssDNA-binding protein complex replication protein A (RPA). The RPA complex is displaced by RAD51, which is the central player in mammalian HR

Published by Bioscientifica Ltd 
Interstrand crosslink (ICL) repair

I

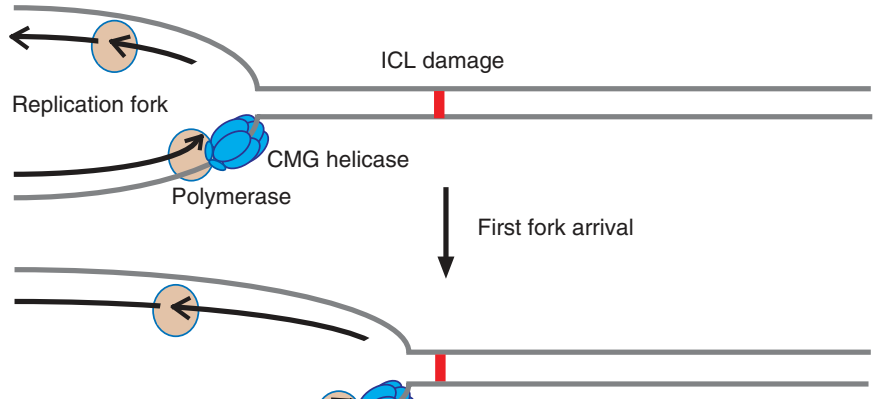

II

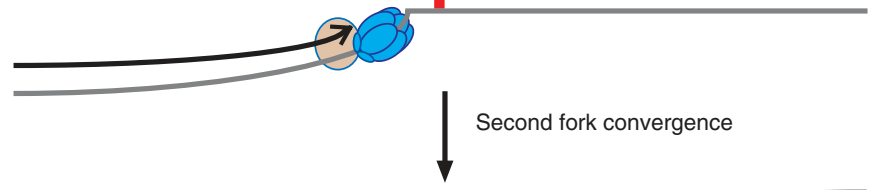

III
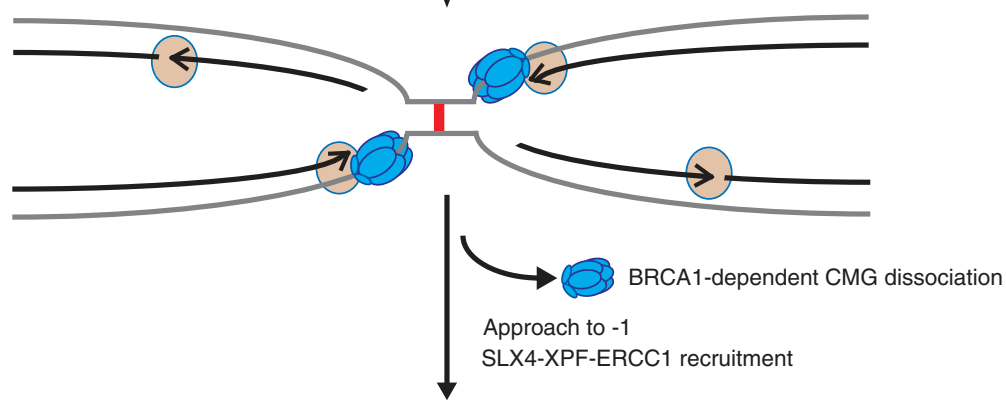

IV
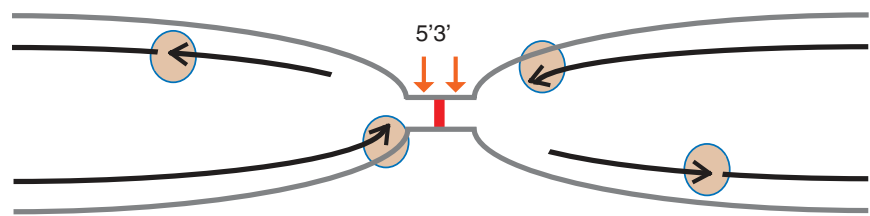

FA pathway-mediated DNA unhooking (dual incision) Translesion synthesis (TLS)

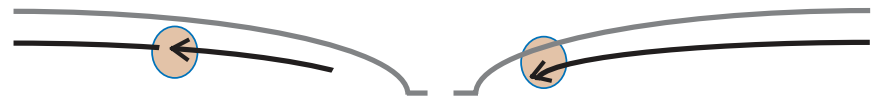

V

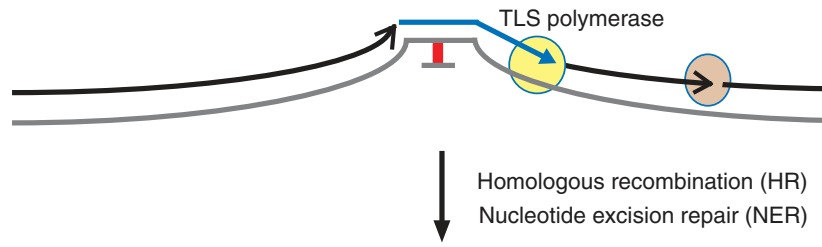

VI

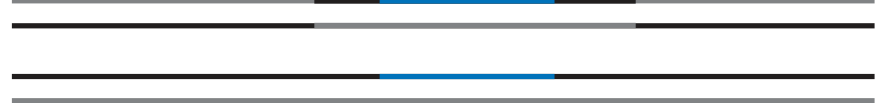

Figure 1

An overview of the ICL repair pathway. When a replisome collides with an ICL (I), the leading strand initially stalls -20 nucleotides away from the lesion (II). After a second fork converges at the ICL, BRCA1 facilitates the dissociation of the CMG complex (consisting of Cdc45, MCM2-7 and GINS) from chromatin at the stalled fork, allowing the leading strand to approach to the -1 nucleotide adjacent to the ICL (III). In the next step, the SLX4-XPF-ERCC1 complex incises the DNA and unhooks the lesion in a FA pathwaydependent manner (IV). Translesion synthesis

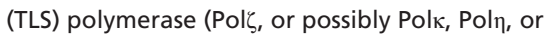
Polt) extends the leading strand synthesis past the unhooked, ICL-associated nucleotide (V), and HR and the nucleotide excision repair (NER) pathway repair the remaining lesion (VI). repair, resulting in the formation of RAD51 nucleoprotein filaments. This reaction is facilitated by mediator proteins including BRCA2 and RAD51 paralogs and can be monitored as the formation of subnuclear small dots (RAD51 foci) by immunohistochemical detection.

RAD51 is a homolog of Escherichia coli RecA, which mediates the core enzymatic reactions in HR (West 2003). It catalyzes (1) searching for a homologous HR template (homology search) and then (2) pairing of the ssDNA-RAD51 filament with the template DNA (strand invasion and homologous pairing) once the filament encounters the appropriate homologous doublestranded DNA. These reactions result in the formation of a D-loop that consists of heteroduplex DNA coated with RAD51 and displaced ssDNA. The next step is DNA repair synthesis initiated from the invading $3^{\prime}$ ssDNA end. In

Published by Bioscientifica Ltd 
Table 1 Hereditary breast and ovarian cancer (HBOC) risk genes.

\begin{tabular}{|c|c|}
\hline Gene & Syndrome with germline mutations \\
\hline$B R C A 1$ & $\mathrm{HBOC}$ \\
\hline$B R C A 2$ & HBOC \\
\hline PTEN & Cowden syndrome, PTEN hamartoma \\
\hline TP53 & Li-Fraumeni syndrome \\
\hline $\mathrm{CDH} 1$ & $\begin{array}{l}\text { Hereditary diffuse gastric cancer } \\
\text { syndrome }\end{array}$ \\
\hline STK11 & Peutz-Jeghers syndrome \\
\hline$N B S 1$ & Nijmegen breakage syndrome \\
\hline NF1 & Neurofibromatosis type I \\
\hline ATM & Ataxia telangiectasia \\
\hline $\mathrm{CHK} 2$ & Li-Fraumeni syndrome \\
\hline FANCJ & Fanconi anemia \\
\hline FANCM & Fanconi anemia \\
\hline PALB2 & Fanconi anemia \\
\hline RAD51C & FA-like syndrome \\
\hline
\end{tabular}

\begin{tabular}{l} 
Functions \\
\hline Homologous recombination \\
Homologous recombination \\
Phosphatidylinositol 3-phosphate, \\
suppresses AKT signaling \\
Transcription factor, regulates cell cycle, \\
apoptosis, senescence \\
E-cadherin gene, maintains cell \\
adherence \\
Serine/threonine kinase, regulates cell \\
polarity \\
Cell cycle checkpoint after DNA \\
damage, member of the MRN complex \\
Negative regulator of Ras signaling \\
PI3 kinase-related kinase, cell cycle \\
checkpoint and DSB repair \\
Activation of cell cycle checkpoint after \\
DNA damage \\
Interstrand crosslink repair \\
Interstrand crosslink repair \\
Interstrand crosslink repair, homologous \\
recombination \\
Interstrand crosslink repair, homologous \\
recombination
\end{tabular}

\begin{tabular}{|c|c|}
\hline Cancer type & Penetrance \\
\hline Breast and ovarian cancer & High \\
\hline Breast and ovarian cancer & High \\
\hline Breast cancer & High \\
\hline Breast and ovarian cancer & High \\
\hline Breast and ovarian cancer & High \\
\hline Breast and ovarian cancer & High \\
\hline Breast cancer & High \\
\hline Breast cancer & High \\
\hline Breast cancer & Moderate \\
\hline Breast and ovarian cancer & Moderate \\
\hline Breast and ovarian cancer & Moderate \\
\hline Breast cancer & Moderate \\
\hline Breast and ovarian cancer & Moderate \\
\hline Breast and ovarian cancer & Moderate \\
\hline
\end{tabular}

most instances in mitotic cells, the extended ssDNA is displaced from the template strand and is then annealed by the other processed single-stranded DNA end (i.e., the other end of the DSB). This mechanism is termed 'synthesis-dependent strand annealing (SDSA) pathway', and the final product does not contain crossover events (non-crossover). In some cases, the recombination intermediates are converted into a 'double Holliday junction' and subsequently resolved by Holliday junction resolvases (e.g., GEN1 or the SLX4 complex) (Garner et al. 2013, Wyatt et al. 2013) (with or without crossover) or the BLM helicase complex (without crossover) ( $\mathrm{Wu}$ \& Hickson 2003). For more complete discussion of HR mechanisms such as their relationship with competing NHEJ (the pathway choice) or Holliday junction resolvases, readers should refer to the recent excellent reviews (Chapman et al. 2012, Sarbajna \& West 2014).

\section{Basic molecular mechanisms of ICL repair}

An ICL covalently bridges two nucleotides on opposite DNA strands and hampers critical DNA transactions such as DNA replication and transcription. Recent studies from Walter's lab using Xenopus egg extracts and plasmid DNA harboring an ICL provided a comprehensive and persuasive view on the detailed mechanisms of ICL repair (Fig. 1) (Räschle et al. 2008, Knipscheer et al. 2009, Long et al. 2011, Duxin \& Walter 2015).
According to this model, two converging replication forks from opposite directions first stall $\sim 20$ bp away $(-20)$ from the ICL, and then leading strand synthesis progresses to the -1 position with respect to the ICL, perhaps after the removal of the CMG helicase. Next, the ICL and ssDNA regions are recognized, leading to the activation of the checkpoint kinase and the FA pathway. The exact mechanism by which these events are accomplished still remains unclear. DNA strands on both sides of the ICL are incised by recruited nucleases, resulting in DSB formation in one of the sister chromatids (unhooking). The DNA replication occurs over the incised ICL by a bypass DNA polymerase specialized in translesion synthesis (TLS), such as REV1 or REV3, perhaps after PCNA monoubiquitination by the RAD18 ubiquitin ligase. The DSB is resected, and the core HR reaction is initiated with the formation of RAD51 filaments. Finally, the short nucleotide fragment that contains the remnant of the ICL is recognized and removed by nucleotide excision repair (NER). How each component of the FA pathway is involved in the ICL repair is described in the following section.

\section{FA, FA pathway and ICL repair}

So far, nineteen 'FA genes' have been identified and are thought to function in the ICL repair pathway (Kitao \& Takata 2011, Kottemann \& Smogorzewska 2013, Bogliolo \& Surrallés 2015, Ceccaldi et al. 2016). These FA pathway

Published by Bioscientifica Ltd 
Table 2 Fanconi anemia (FA) and FA-like syndrome genes. There are already 20 distinct genes identified in these syndromes, and all proteins are required for interstrand crosslink (ICL) repair. Heterozygous germline mutations in several genes are also related to $\mathrm{HBOC}$.

\begin{tabular}{|c|c|c|c|c|}
\hline Gene & Synonym & Functions & Symptoms & Heterozygous germline mutation \\
\hline FANCA & & $\begin{array}{l}\text { Component of the FA core } \\
\text { complex }\end{array}$ & FA pathologies & \\
\hline FANCB & & $\begin{array}{l}\text { Component of the FA core } \\
\text { complex }\end{array}$ & FA pathologies & \\
\hline FANCC & & $\begin{array}{l}\text { Component of the FA core } \\
\text { complex }\end{array}$ & FA pathologies & \\
\hline FANCD1 & $B R C A 2$ & $\begin{array}{l}\text { HR repair, recruits RAD51 onto } \\
\text { DNA, interacts with FANCN, } \\
\text { Stalled replication fork protection }\end{array}$ & $\begin{array}{l}\text { FA pathologies, not all patients } \\
\text { show bone marrow failure }\end{array}$ & $\mathrm{HBOC}$ \\
\hline FANCD2 & & $\begin{array}{l}\text { Ubiquitinated after DNA damage, } \\
\text { Stalled replication fork protection }\end{array}$ & FA pathologies & \\
\hline FANCE & & $\begin{array}{l}\text { Component of the FA core } \\
\text { complex }\end{array}$ & FA pathologies & \\
\hline FANCF & & $\begin{array}{l}\text { Component of the FA core } \\
\text { complex }\end{array}$ & FA pathologies & \\
\hline FANCG & $X R C C 9$ & $\begin{array}{l}\text { Component of the FA core } \\
\text { complex }\end{array}$ & FA pathologies & \\
\hline FANCI & & $\begin{array}{l}\text { Ubiquitinated after DNA damage, } \\
\text { required for FA core complex } \\
\text { activation }\end{array}$ & FA pathologies & \\
\hline FANCJ & $B A C H 1, B R I P 1$ & $\begin{array}{l}\text { ICL repair, HR repair, } 3^{\prime} \text { to } 5^{\prime} \\
\text { helicase, interacts with } B R C A 1\end{array}$ & FA pathologies & $\mathrm{HBOC}$ \\
\hline FANCL & PHF9 & $\begin{array}{l}\text { Component of the FA core } \\
\text { complex, E3 ubiquitin ligase }\end{array}$ & FA pathologies but no cancers & \\
\hline FANCM & Hef & $\begin{array}{l}\text { DNA translocase, required for } \\
\text { FANCI-D2 ubiquitination }\end{array}$ & $\begin{array}{l}\text { Unknown, the only known patient } \\
\text { also has a FANCA mutation }\end{array}$ & $\mathrm{HBOC}$ \\
\hline FANCN & PALB2 & $\begin{array}{l}\text { HR repair, interacts with BRCA1 } \\
\text { and } B R C A 2 \text {, facilitates } B R C A 2 \\
\text { function }\end{array}$ & FA pathologies & $\mathrm{HBOC}$ \\
\hline FANCO & RAD51C & $\begin{array}{l}\text { RAD51 paralog, HR repair, RAD51 } \\
\text { nucleoprotein filament stability }\end{array}$ & $\begin{array}{l}\text { FA-like syndrome, no bone } \\
\text { marrow failure and cancer }\end{array}$ & \\
\hline FANCP & $S L X 4$ & $\begin{array}{l}\text { Coordinates XPF-ERCC1, interacts } \\
\text { with MUS81-EME1 and SLX1 } \\
\text { nucleases }\end{array}$ & FA pathologies & \\
\hline FANCQ & $X P F, E R C C 4$ & $\begin{array}{l}\text { Endonucleases, associates with } \\
\text { ERCC1, ICL unhooking }\end{array}$ & FA pathologies & $\mathrm{HBOC}$ \\
\hline FANCR & RAD51 & HR repair, stalled fork protection & $\begin{array}{l}\text { FA-like syndrome, no bone } \\
\text { marrow failure and cancer }\end{array}$ & \\
\hline FANCS & $B R C A 1$ & $\begin{array}{l}\text { HR repair, promotes RAD51 } \\
\text { recruitment, interacts with } \\
\text { FANCN }\end{array}$ & $\begin{array}{l}\text { FA-like syndrome, no bone } \\
\text { marrow failure }\end{array}$ & $\mathrm{HBOC}$ \\
\hline FANCT & UBE2T & $\begin{array}{l}\text { E2 ubiquitin-conjugating enzyme } \\
\text { for FANCD2 complex, interacts } \\
\text { with FANCL }\end{array}$ & FA pathologies & \\
\hline FANCU & $X R C C 2$ & $\begin{array}{l}\text { RAD51 paralog, HR repair, RAD51 } \\
\text { nucleoprotein filament stability }\end{array}$ & $\begin{array}{l}\text { FA-like syndrome, no bone } \\
\text { marrow failure }\end{array}$ & \\
\hline
\end{tabular}

genes are classified into three subgroups by their functional roles in the ICL repair as explained below (Fig. 3).

\section{The FA core complex and the key downstream complex consisting of FANCD2 and $\mathrm{FANCI}$}

The first FA group is the 'ubiquitination module,' which comprises the E3 ubiquitin ligase complex (termed FA core complex) and its substrates, the FANCD2-FANCI (D2-I) complex (Fig. 3). These genes have been shown to function in HR, mainly based on Jasin's recombination assay. In this assay, a chromosomal DSB is induced within an integrated recombination substrate by a plasmidencoded rare restriction enzyme I-SceI, which recognizes a specific 18 bp sequence (Rouet et al. 1994). The HR repair pathway then uses homologous DNA segments placed either upstream or downstream of the DSB, resulting in

Published by Bioscientifica Ltd 


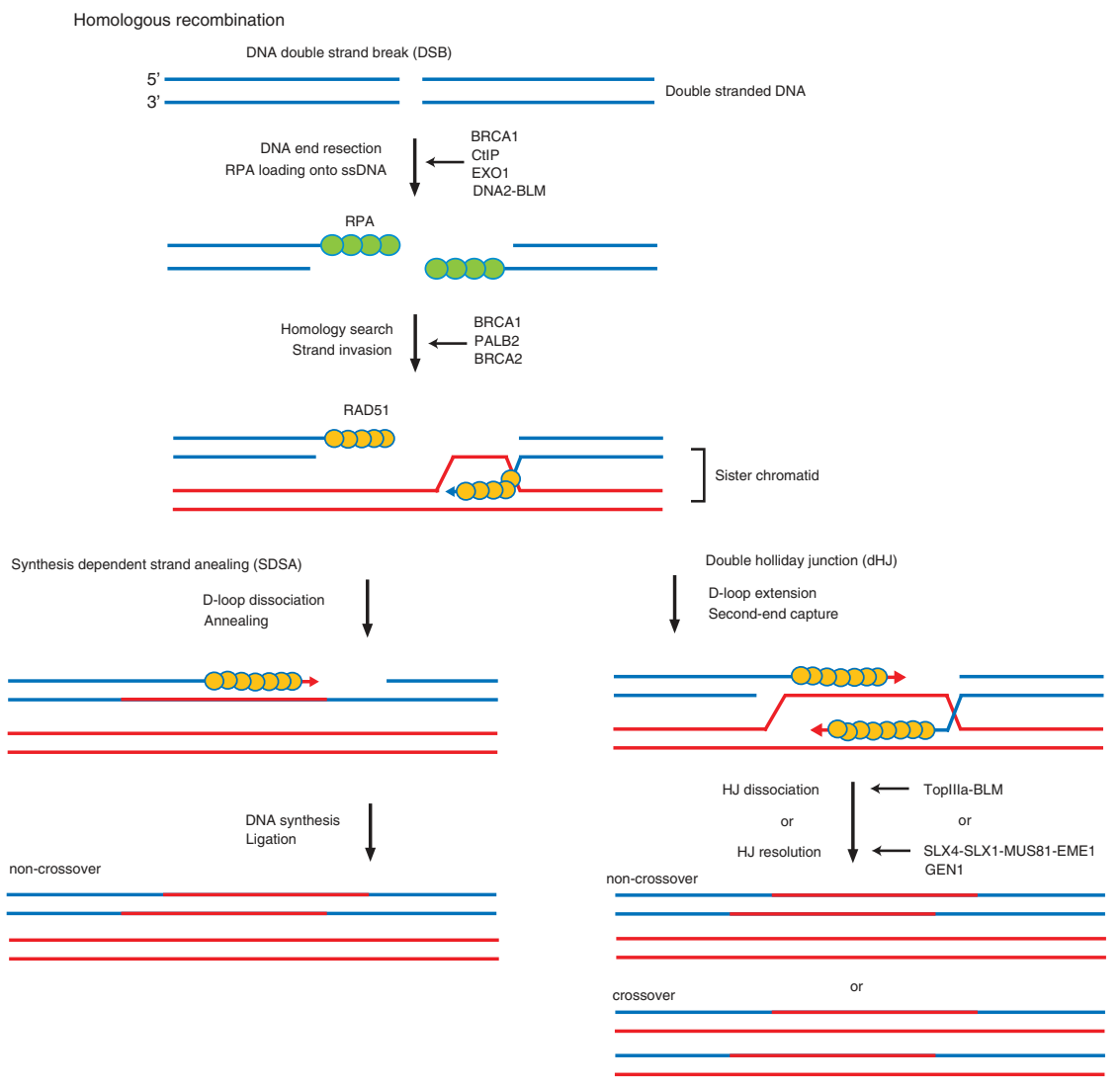

\section{Figure 2}

Schematic of HR pathway. When a double-strand break (DSB) is generated after DNA replication during $S$ and $\mathrm{G} 2$ phase, both strands are resected in the $5^{\prime}$ to $3^{\prime}$ direction to generate $3^{\prime}$ overhangs. Almost immediately, replication protein A (RPA) is loaded onto the single-stranded (ss) DNA, and then replaced by a RAD51 nucleoprotein filament in a process requiring BRCA1-PALB2-BRCA2. RAD51 carries out strand invasion of the sister chromatid by the ssDNA tail and extends the resulting $D$-loop formation. In synthesisdependent strand annealing (SDSA), the D-loop structure quickly dissociates from the ssDNA after synthesis of a complementary single strand, and then another strand anneals with a processed ssDNA. An alternate pathway forms a double Holliday junction (dHJ). After second end capture and fill-in synthesis, the Holliday junction is dissociated by the Toplll $\alpha$-BLM complex or resolved by resolvase complexes that contain SLX4, MUS81 and GEN1. the expression of the neomycin resistance gene or GFP. In cells lacking these FA genes, the efficiency of HR repair is substantially decreased in chicken DT40 cells (Yamamoto et al. 2003, 2004) or mildly decreased in human cells (Nakanishi et al. 2005). How these proteins function in HR is still under investigation; however, milder HR defects in human cells may indicate that these 'ubiquitination module' FA genes do not provide 'core' HR functions. It seems more likely that they modulate the function of the core HR machineries (such as BRCA2 or CtIP, see the 'The nucleases in the FA pathway' section below) or TLS polymerase (Kim et al. 2012) or they may regulate histone dynamics (Sato et al. 2012). This module is reported to be required for incision/unhooking of the crosslink during ICL repair (Knipscheer et al. 2009, Klein Douwel et al. 2014, Duxin \& Walter 2015), and thus functions in the conversion of an ICL to a DSB.

The FA core complex includes FA proteins FANCA, B, C, E, F, G, J, L, M and FA-associated proteins, such as FAAP24, FAAP20 and FAAP100 (Kottemann \& Smogorzewska 2013, Bogliolo \& Surrallés 2015, Ceccaldi et al. 2016). In response to an ICL and/or a stalled replication fork, the FA core complex is somehow activated downstream of the checkpoint kinase ATR-ATRIP through multiple phosphorylation of FANCI
(Ishiai et al. 2008), FANCM (Singh et al. 2013) or FANCA (Collins et al. 2009) and monoubiquitinates FANCD2 at lysine 561, which is a critical activating event in the FA pathway (Garcia-Higuera et al. 2001, Matsushita et al. 2005). Recent studies indicate that ubiquitinlike with PHD and RING finger domain 1 (UHRF1) protein functions as an ICL recognition factor and may participate in these steps (Liang et al. 2015, Tian et al. 2015). Recently, we and two different groups identified UBE2T, which encodes an E2 ubiquitin-conjugating enzyme, as a causative gene for FA (Hira et al. 2015, Rickman et al. 2015, Virts et al. 2015). UBE2T/FANCT is essential for this monoubiquitination event to proceed. FANCI is a paralog of FANCD2 and its binding partner and also undergoes monoubiquitination dependent on the core complex and monoubiquitination of FANCD2 (Smogorzewska et al. 2007, Ishiai et al. 2008). The monoubiquitinated D2-I complex (often referred to as the 'ID complex') is recruited and accumulates in foci at damaged chromatin, perhaps by binding to the stalled fork itself (with or without an ICL) (Joo et al. 2011, Liang et al. 2016). Focus formation is likely to function as a platform to recruit the numerous proteins required for homologous recombination (HR) and translesion synthesis (TLS) to the damage site.

Published by Bioscientifica Ltd. 


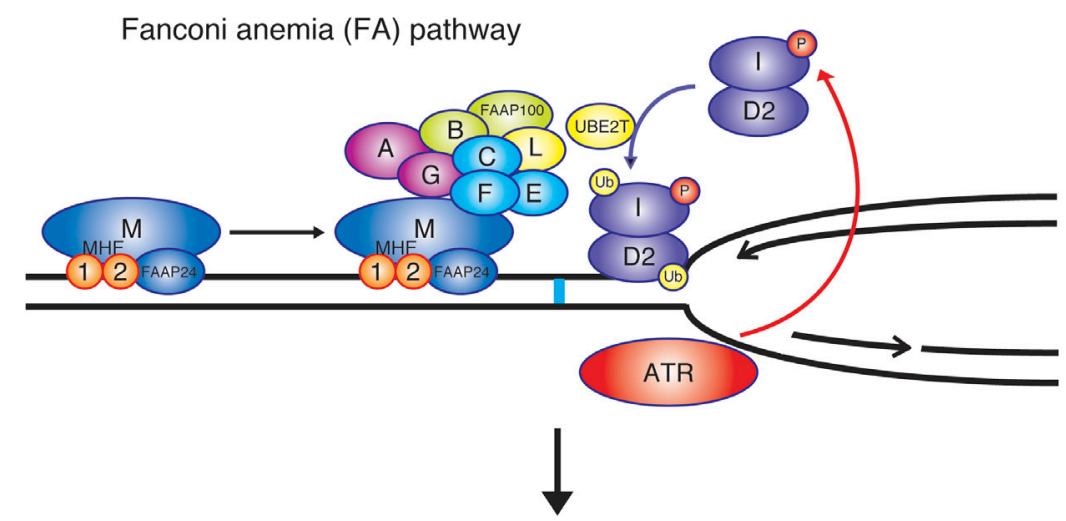

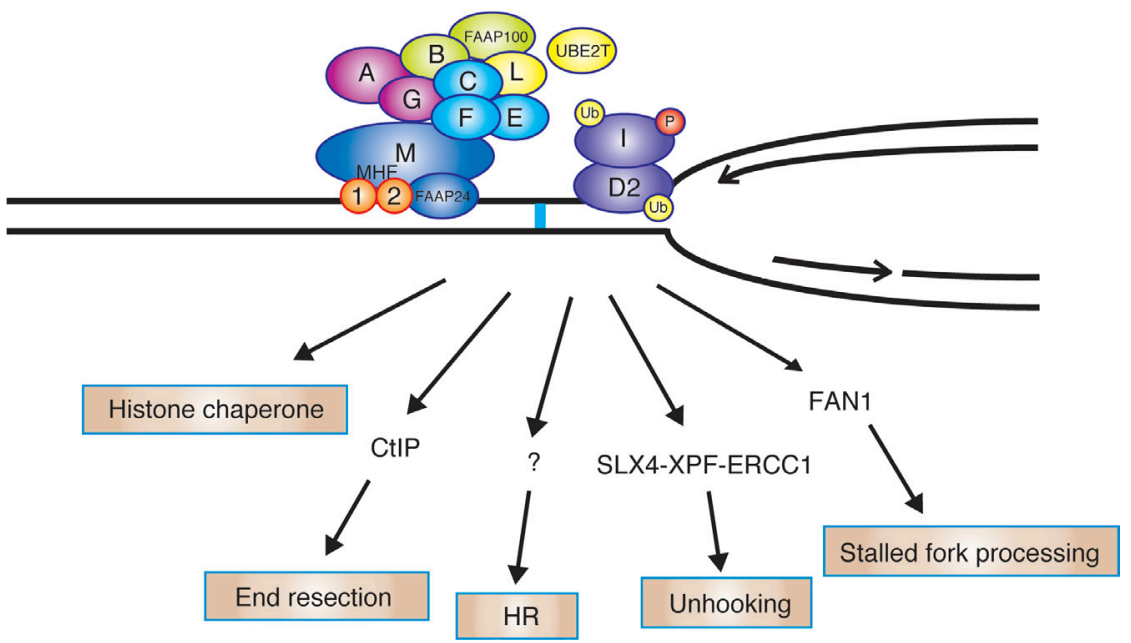

Figure 3

The mechanism of FA pathway activation. Upon replication fork stalling, FANCM-FAAP24-MHF1/2 complex binding at the ICL lesion activates ATR signaling, followed by the recruitment of the FA core complex. FANCI is phosphorylated by ATR, and subsequently, the FA core complex with UBE2T mediates the monoubiquitination of the FANCI-FANCD2 (D2-I) complex. This modification targets the D2-I complex to chromatin and leads to multiple events that repair the ICL lesion.
However, the mechanism by which it orchestrates the repair machinery is still not entirely clear.

FANCM is a human homolog of the archeal helicase/ nuclease Hef gene (Komori et al. 2004), which encodes a DNA translocase (Meetei et al. 2005). It is necessary for chromatin loading of the FA core complex (Kim et al. 2008) and checkpoint activation (Huang et al. 2010), and it plays a distinct role in bypass replication past an ICL by promoting 'traverse' of the lesion (Huang et al. 2013). Biallelic FANCM mutations were identified in a single patient, but the defects in cells from the patient could not be reversed by the expression of wild-type FANCM (Meetei et al. 2005). This was later found to be due to the presence of simultaneous mutations in FANCA (Singh et al. 2009). Thus, to date, there have been no human FA patients identified with causative mutations solely in FANCM. Furthermore, in the Finnish population, individuals with homozygous loss-of-function FANCM mutations do not show any FA phenotype (Lim et al. 2014), suggesting that FANCM is not a bona fide FA gene, though it clearly contributes to the function of the FA pathway and is a candidate HBOC gene (Kiiski et al. 2014, Peterlongo et al. 2015).
As FANCD2 and FANCI form a dimeric complex that seems quite stable (Sato et al. 2012), and they are mutually dependent on each other for activating monoubiquitination (Smogorzewska et al. 2007, Ishiai et al. 2008), it has been assumed that these proteins should function together. However, it was discovered recently that FANCI, not FANCD2, has an upstream role for foci formation of the core complex components, like FANCA (Castellà et al. 2015). It would be interesting to determine which molecule (FANCM vs FANCI) is furthest upstream in localizing the core complex. Further, ATRphosphorylated FANCI regulates the replicative helicase MCM complex, thereby suppressing dormant origin firing as a distinct function outside of the FA pathway (Chen et al. 2015). FANCD2 was also found to interact with MCM helicase independently of its monoubiquitination, where it restrains DNA synthesis in stressed cells, attenuating cell proliferation and carcinogenesis (Lossaint et al. 2013).

\section{The nucleases in the FA pathway}

One of the essential events in ICL repair is an incision of the crosslink, which is called 'unhooking'. In the

Published by Bioscientifica Ltd 
current understanding, this event depends on the monoubiquitinated D2-I complex and is carried out by the nuclease complex SLX4-XPF (Knipscheer et al. 2009, Long et al. 2011, Kim et al. 2013, Hodskinson et al. 2014, Klein Douwel et al. 2014, Duxin \& Walter 2015). SLX4/FANCP is a large protein that itself can function as a scaffold and is mutated in FA-P patients (Kottemann \& Smogorzewska 2013, Bogliolo \& Surrallés 2015, Ceccaldi et al. 2016). SLX4 accumulates in the chromatin containing DNA damage via its tandem UBZ4 domains. It has been reported that SLX4 is recruited by monoubiquitinated FANCD2 (Yamamoto et al. 2011). However, there is a conflicting report (Lachaud et al. 2014), and the UBZ domain is generally considered to bind to K63-linked polyubiquitin (Lachaud et al. 2014). How SLX4 is tethered to the sites of damage and how the D2-I complex affects unhooking are important issues that need to be resolved.

Of note, biallelic mutations in XPF that specifically affect the cellular sensitivity to ICLs but not UV were identified among unclassified FA patients (Bogliolo et al. 2013, Kashiyama et al. 2013). Now this group of patients is termed FA-Q. XPF was originally identified as one of the causative genes for a UV-sensitive disorder - xeroderma pigmentosum (XP). This is an interesting example of distinct phenotypes due to specific mutations affecting different features of a single protein.

Another nuclease FAN1, which associates with monoubiquitinated FANCD2, was also thought to function for ICL repair in an FA pathway-dependent manner. However, quite recently, Lachaud and coworkers demonstrated that FANCD2 monoubiquitinationdependent FAN1 recruitment is dispensable for ICL repair function of FAN1 but is required for DNA replication fork progression and the prevention of chromosome abnormalities (Lachaud et al. 2016).

CtIP is an important nuclease required for end resection of DSBs and has been shown to interact with BRCA1 as well as the MRN complex. We and others have identified CtIP as a novel interactor of FANCD2 (Murina et al. 2014, Unno et al. 2014). MMC-induced CtIP recruitment to damage foci is dependent on the interaction with FANCD2, and this recruitment appears to be required for end resection of the DSB generated after unhooking of the ICL. CtIP depletion mildly sensitizes cells to MMC treatment, consistent with the role of CtIP downstream of FANCD2 (Murina et al. 2014, Unno et al. 2014).

\section{The core HR genes in the FA pathway}

The group of HR/FA genes that operate in the repair ICLs includes BRCA2/FANCD1, Brip1/FANCJ, PALB2/FANCN, RAD51C/FANCO and XRCC2/FANCU (Kottemann \& Smogorzewska 2013, Bogliolo \& Surrallés 2015, Ceccaldi et al. 2016). BRCA1/FANCS (Domchek et al. 2013, Sawyer et al. 2015) and RAD51/FANCR (Ameziane et al. 2015, Wang et al. 2015) genes are recent and surprising additions to this group. Many of these are HBOC genes (Table 1) and RAD51 mediators. Thus, they function as the core HR machinery.

BRCA2/FANCD1 was identified as the first core HR gene implicated in FA (Howlett et al. 2002). As it is a wellknown tumor suppressor and HBOC gene, this led to the exciting possibility that mutations in other FA genes would also cause HBOC. However, this prediction turned out to be a bit too simplistic. Genes encoding the core complex components and FANCD2/FANCI are unlikely to be a high-penetrance HBOC gene (Seal et al. 2003, Berwick et al. 2007), although there are some reports indicating FANCM (Kiiski et al. 2014, Peterlongo et al. 2015) or FANCC (Berwick et al. 2007, Thompson et al. 2012) could be considered as candidate HBOC genes.

PALB2/FANCN is the partner and localizer of BRCA2 (Xia et al. 2006), and also binds BRCA1, linking the two critical HR proteins BRCA1 and BRCA2 (Sy et al. 2009, Zhang et al. 2009). Interaction with BRCA1 facilitates the recruitment of PALB2-BRCA2 complex to the DNA damage sites. PALB2 stabilizes BRCA2 and critically regulates the functions of BRCA2 as a mediator for RAD51. A recent study revealed that PALB2-BRCA1 interaction is a regulatory point during cell cycle progression (see the 'Additional regulators of HR and RAD51 function' section below) (Orthwein et al. 2015). Strikingly, FA-D1 and FA-N patients develop leukemia and kidney or brain tumors at a very early age, with much higher frequency than other FA complementation groups (Hirsch et al. 2004, Wagner et al. 2004, Reid et al. 2007).

Five RAD51 paralogs (e.g., RAD51B, RAD51C, RAD51D, $\mathrm{XRCC2}$, XRCC3) interact in two distinct complexes (Masson et al. 2001) - RAD51B/C/D/XRCC2 (BCDX2) and RAD51C/XRCC3 (CX3). In addition to BRCA2, they also function as RAD51 mediators. It was confirmed that these two complexes are functionally different from each other (Yonetani et al. 2005). Furthermore, analysis of the C. elegans Rad51 homolog revealed that RAD51 paralogs remodel presynaptic filaments of RAD51 into 
a stabilized and flexible conformation, which prevents ssDNA degradation by nucleases and RAD51 dissociation (Taylor et al. 2015). Among these paralog genes, RAD51C or XRCC2 mutations were reported in FA-like patients with physical characteristics and chromosome breakage test results similar to FA. Thus, these patients are classified as FA-O (Vaz et al. 2010) or FA-U group (Shamseldin et al. 2012). Cells lacking RAD51 paralog genes generally exhibit a similar phenotype and deficiency in HR (Takata et al. 2000, 2001); therefore, it is possible that humans defective in any of the paralog genes may display a similar FA-like phenotype.

Recently, biallelic mutations in the BRCA1 gene have finally been identified in two patients with early-onset ovarian or breast cancer (Domchek et al. 2013, Sawyer et al. 2015). Diepoxybutane (DEB) induced chromosome breakage test was performed in one of them and found to be positive (Domchek et al. 2013, Sawyer et al. 2015), leading to the designation of FANCS. BRCA1/FANCS is known to target BRCA2/FANCD1 to the DSB site via interaction with PALB2/FANCN (Zhang et al. 2009). It has been reported that one of the BRCA1 interactors, Brip1 helicase, is responsible for the FA-J subgroup. These patients display a typical FA phenotype, albeit not a particularly severe one (Kitao \& Takata 2011, Kottemann \& Smogorzewska 2013, Bogliolo \& Surrallés 2015, Ceccaldi et al. 2016). It was also recently discovered that a monoallelic mutation in RAD51 can give rise to FA-like symptoms by a dominant negative mechanism (termed FA-R subgroup) (Ameziane et al. 2015, Wang et al. 2015).

Interestingly, although FA-D1/N/J patients display the usual constellation of FA symptoms, the patients belonging to $\mathrm{FA}-\mathrm{O} / \mathrm{R} / \mathrm{S}$ subgroups do not appear to develop BMF (Bogliolo \& Surrallés 2015). Although it is possible that they eventually develop BMF in long-term follow-up, it seems inappropriate to classify these patients as having FA, and at the moment, they should be called FA-like. It will be highly interesting to clarify why these patients do not (or tend not to) develop hematopoietic stem cell failure because patients belonging to FA-D1/N/ $\mathrm{J} / \mathrm{O} / \mathrm{R} / \mathrm{S}$ all seem to have a similar pathophysiology due to HR deficiency. Of note, a recent study demonstrated that BRCA1 deficiency, specifically in mouse bone marrow, causes hematopoietic defects (Vasanthakumar et al. 2016).

\section{Structure and function of BRCA2 in the HR pathway}

\section{General features}

The BRCA2 primary structure is depicted in Fig. 4. BRCA2 is a huge protein that encompasses 3418 amino acids in humans. Shahid and coworkers recently revealed the structure of full-length BRCA2 as being a dimer, using cryo-EM 3D reconstruction (Shahid et al. 2014). The sequence conservation among BRCA2 orthologs among various species is mostly limited to the N-terminal, the middle part, and the C-terminal regions; therefore, these regions may be more important for genome maintenance (Takata et al. 2002).

\section{$\mathrm{N}$-terminus}

In the BRCA2 N-terminus, there is a region that binds to PALB2/FANCN (Buisson et al. 2010, Menzel et al. 2011). PALB2 facilitates BRCA2 localization and RAD51
Human BRCA1 (1863 aa)

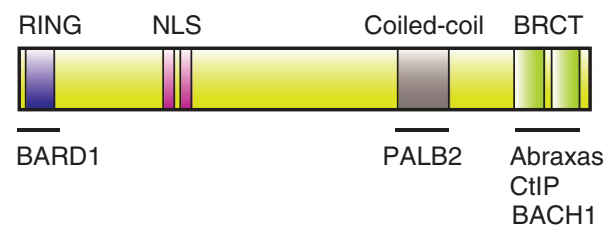

Human BRCA2 (3418 aa)

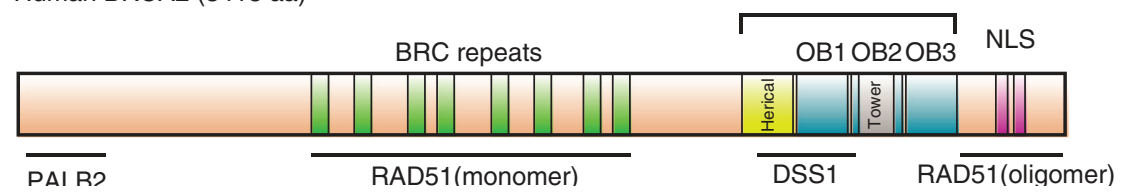

\section{Figure 4}

The primary structures of human BRCA1 and BRCA2. BRCA1 consists of 1863 amino acids. The RING domain is in the N-terminus and partly overlaps with the BARD1-binding region. BRCA1 interacts with PALB2 via a coiled-coil region in the C-terminus. The BRCT motif is a phosphorylated protein-binding sequence, and this motif mediates the association of BRCA1 with Abraxas, CtIP and BACH1, which are all known factors in DSB repair. BRCA2 comprises 3418 amino acids. The PALB2 binding region is located in the amino $(\mathrm{N})$ terminus. In the center, BRCA2 harbors eight BRC repeats, which constitute a binding region for RAD51 monomers. In the carboxy (C) terminus, a DNA-binding domain contains three $\mathrm{OB}$ folds and a region that interacts with DSS1. The C-terminal region of $B R C A 2$ is also important for the formation of the RAD51 nucleoprotein filament and BRCA2 nuclear localization. 
chromatin loading at the damage site. This region of BRCA2 was also reported to bind to EMSY (HughesDavies et al. 2003). The EMSY-binding region of BRCA2 is encoded by exon 3, which is known to be deleted in cancer (Hughes-Davies et al. 2003, Cousineau \& Belmaaza 2011). The EMSY locus is amplified in sporadic breast cancer (13\%) and higher-grade ovarian cancer (17\%). At the cellular level, EMSY overexpression leads to defective HR (Cousineau \& Belmaaza 2011), consistent with the notion that the EMSY-binding region of BRCA2 is likely to coincide or overlap with the PALB2-interacting region.

\section{BRC repeats}

In the middle part (the residues between 990 and 2100), BRCA2 harbors eight tandem BRC repeats, each consisting of about 30 amino acids, which are well conserved across human, mouse, rat and chicken (Takata et al. 2002, Yang et al. 2002). Not only the sequences themselves but also the spacing between them is well conserved across species. These individual repeats are the primary motifs through which BRCA2 binds to RAD51, and they are essential for BRCA2 function in HR as shown by mouse knockout studies (Connor et al. 1997, Ludwig et al. 1997, Friedman et al. 1998, Patel et al. 1998, Jonkers et al. 2001). BRCA2 stimulates RAD51 assembly onto ssDNA, and the BRC repeats are critical for this, perhaps by acting cooperatively. It is still unclear whether each BRC repeat can have a distinct function or they can act in a redundant manner. Supporting the former possibility, BRC missense mutations disrupting the interaction with RAD51 have been identified in breast cancer patients (Pellegrini et al. 2002), and conservation between the repeats in a given species is relatively low. It was also shown that BRC1-4 has a higher affinity to RAD51 monomers than BRC5-8; therefore, BRC repeats may not be functionally equivalent (Carreira \& Kowalczykowski 2011). On the other hand, it was shown that an artificial fusion gene consisting of a single BRC repeat and RPA can display HR function (Saeki et al. 2006).

\section{DBD}

In the C-terminus of BRCA2, there is a DNA-binding domain (DBD) containing three oligonucleotidebinding (OB) folds, a Tower domain and a helix-turnhelix $(\mathrm{HTH})$ motif. The DBD interacts not only with single-stranded DNA but also with DSS1 (Yang et al. 2002), which is a small 70 amino acid protein identified from the genomic region on chromosome $7 q 21.3$ that was deleted in an inherited developmental syndrome split hand/foot malformation. Recently, DSS1 has been reported to target BRCA2 to RPA (Zhao et al. 2015), and it functions in the replacement of RPA with RAD51 on resected ssDNA (see the 'Mediator function of BRCA2 in loading of RAD51 onto ssDNA' section below).

According to the breast cancer information core database, more than $25 \%$ of cancer-associated missense mutations map to the C-terminal region (residues 2500-2850) (Szabo et al. 2000), which includes the sequence through which BRCA2 binds to DSS1 (Jeyasekharan et al. 2013). Recent analysis of cancer-associated BRCA2 mutations has led to the identification of a nuclear export signal (NES) in the C-terminal region of BRCA2 (Jeyasekharan et al. 2013). The NES is masked by the interaction with DSS1. Interestingly, a common cancer-associated BRCA2 mutation, D2723H, impairs the binding of BRCA2 to DSS1, leading to its mislocalization to the cytoplasm and disruption of RAD51 loading onto damaged chromatin. Notably, this mutation is likely to decrease RAD51 foci formation even in the presence of normal BRCA2, suggesting that this mutation acts in a dominant-negative manner.

The three OB domains in BRCA2 are structurally very similar to the canonical OB fold, like the one in RPA (Murzin 1993), consisting of a highly curved $\beta$-sheet that closes on itself to form a $\beta$ barrel. Both the OB2 and OB3 folds have the obvious groove that is characteristic of the ssDNAbinding sites of canonical OB folds (Yang et al. 2002). Using electron microscopy, Thorslund and coworkers unveiled that purified human BRCA2 selectively binds to single-stranded DNA in tailed duplexes and replication fork structures (Thorslund et al. 2010). The Tower domain is capable of binding duplex DNA; however, full-length BRCA2 is likely to interact primarily with ssDNA.

\section{C-terminal RAD51 binding site}

Esashi and coworkers demonstrated that RAD51 directly interacts with a region near the BRCA2 C-terminal end that has no homology with the BRC repeats. Phosphorylation of this region at Ser3291 by cyclindependent kinase (CDK) disrupts the C-terminal BRCA2-RAD51 interaction (Esashi et al. 2005). The level of phosphorylation at this residue is low during $\mathrm{S}$ phase when RAD51 activity is high and increases as the cell enters mitosis. DNA damage elicits a block of this phosphorylation, suggesting that this modification can modulate BRCA2 activity. Unlike BRC repeats, the C-terminal RAD51-binding domain selectively interacts with RAD51 oligomers and RAD51 nucleoprotein

Published by Bioscientifica Ltd 
filaments. This region protects RAD51 nucleoprotein filaments formed on ssDNA from dissociation by the BRC repeats. The FA-D1 patient cell line, EUFA423, expresses truncated BRCA2 lacking the C-terminal 192 amino acid residues, which means that the C-terminal RAD51-binding domain (residues 3265-3330) is lost in this patient. This cell line showed impairments in RAD51 focus formation and HR activity (Wang et al. 2004). In addition, an individual with HBOC has been reported to carry a deletion of the C-terminal 224 residues of BRCA2 (Håkansson et al. 1997). These observations underscore the importance of tumor suppression of the C-terminal RAD51-binding region that regulates RAD51 nucleoprotein filament formation (Esashi et al. 2007, Ayoub et al. 2009).

\section{Mediator function of BRCA2 in loading of RAD51 onto SSDNA}

RAD51 protein itself can bind to both ssDNA and dsDNA. In HR, because RAD51 must initially bind to resected ssDNA tails at the DSB, and the ssDNA is quickly coated with RPA, RAD51 requires a targeting factor that mediates its interaction with ssDNA. It has been shown that fulllength purified human BRCA2 is able to enhance RAD51 presynaptic assembly on RPA-coated ssDNA, promoting RPA-RAD51 exchange. BRCA2 can stimulate RAD51 ssDNA binding in vitro, while inhibiting the ability of RAD51 to bind dsDNA (Carreira et al. 2009, Shivji et al. 2009). Mechanistically, BRCA2 stabilizes ATP-bound RAD51-ssDNA filaments by blocking ATP hydrolysis (Carreira et al. 2009, Jensen et al. 2010). Unlike yeast Rad52, which plays a dominant mediator role for yeast Rad51, BRCA2 does not bind RPA directly. How, then, does BRCA2 regulate RPA-RAD51 exchange?

A key factor turns out to be DSS1, the small and highly acidic protein that interacts with OB1 of BRCA2 (Yang et al. 2002). Purified human DSS1 in the presence of BRCA2 stimulates RAD51 binding to RPA-covered ssDNA, compared with BRCA2 alone (Liu et al. 2010). In contrast, DSS1 alone does not activate RAD51 binding to RPAssDNA. Furthermore, Zhao and coworkers demonstrated that DSS1 targets BRCA2 to RPA, and DSS1 functions as a DNA mimic to promote the removal of RPA from ssDNA, thereby promoting exchange with RAD51 on ssDNA (Zhao et al. 2015).

It is known that there are other molecules involved in RAD51 regulation. These include RAD51AP1 (Wiese et al. 2007) and TONSL/MMS22L (Duro et al. 2010, O'Donnell et al. 2010). Further analysis will shed more light on the possible interplay between these proteins and $\mathrm{HR}$ mechanisms underlying disorders like FA or HBOC.

\section{Additional regulators of HR and RAD51 function}

XPG, which is affected in xeroderma pigmentosum complementation group $\mathrm{G}$ (XP-G), has been reported to form a complex with BRCA2 and DSS1. Trego and coworkers searched for novel XPG partners and unexpectedly found that XPG interacts with BRCA2, RAD51 and PALB2 (Trego et al. 2016). XPG forms foci in $S$ phase, but not in G1 cells. Because XPG depletion caused a decreased presence of RAD51 and BRCA2 in the chromatin fraction, this protein is likely to contribute to HR.

Foci formation by proteins involved in $\mathrm{HR}$, including BRCA1 and RAD51, is tightly regulated during the cell cycle, and they normally accumulate at the site of DNA damage in S and G2 phase, when the cell has sister chromatid DNA. The mechanism by which BRCA1 foci formation is antagonized in G1 phase by proteins that inhibit DNA end resection, such as 53BP1 and RIF1, has been revealed recently (Chapman et al. 2013, Escribano-Diaz et al. 2013, Zimmermann et al. 2013). In addition to this mechanism, it was recently reported that PALB2-BRCA2 cannot bind to BRCA1 specifically in G1 phase owing to the ubiquitination of PALB2. This modification is mediated by the KEAP1-CRL3 ubiquitin ligase, leading to the suppression of HR in G1 (Orthwein et al. 2015). Furthermore, this PALB2 ubiquitination is antagonized by a deubiquitinase USP11. Interestingly, KEAP1 mutations have been reported in breast cancers (Hartikainen et al. 2015).

\section{Genome maintenance and tumor suppression by BRCA2}

As discussed previously, monoallelic BRCA2 mutation causes HBOC, whereas biallelic mutations are characteristic of the FA-D1 subgroup, which displays a particularly severe form of FA, with very early onset of leukemia and solid tumors (Hirsch et al. 2004, Wagner et al. 2004). The malignancies observed in FA-D1 patients are not breast or ovarian cancer; however, this is not surprising because these patients are infants whose endocrine and reproductive systems are immature. BRCA1-deficient breast cancers are typically 'basal-like' and 'triple negative' for epidermal growth factor receptor 2 (HER2), progesterone receptor and estrogen receptor, and they are more recalcitrant to conventional therapy. On the other hand, breast cancer

Published by Bioscientifica Ltd. 
stemming from mutated $B R C A 2$ is clinically categorized as similar to a common sporadic form of breast cancer (Roy et al. 2011). The reason why similar HR deficiencies lead to such distinct clinical entities is still poorly understood (Roy et al. 2011).

In line with the two-hit hypothesis proposed by Knudson (1971), it has been considered that the malignant cells in patients carrying monoallelic BRCA2 mutations obligatorily harbor $\mathrm{LOH}$ affecting the wild-type allele, leading to the loss of $B R C A 2$ function. However, a recent study showed that out of 90 BRCA-deficient breast cancers, ten cases did not lose chromosomes that harbored normal copies of $B R C A$ genes and did not show signatures that indicate loss of $B R C A$ functions (NikZainal et al. 2016). Furthermore, loss of mutant alleles can occur in BRCA-associated breast cancer (King et al. 2007). Thus, in addition to the loss of all BRCA function, $B R C A$ haploinsufficiency may also promote carcinogenesis, and some of the cancers arising in the HBOC patients may not be HR deficient. Indeed, $B R C A 1^{+/-}$mutated cells are defective in response to replication stress (Pathania et al. 2014). As studies on mice showed (Ludwig et al. 1997, Jonkers et al. 2001), in carcinogenic steps, the cells tend to lose Tp53 (or an equivalent checkpoint gene) before loss of BRCA/HR function to avoid cell death and/or senescence.

\section{Therapeutic implications of HR defects in $\mathrm{HBOC}$}

Defective HR is an important target for chemotherapy in HBOC patients (Konstantinopoulos et al. 2015). Platinumbased chemotherapy is a well-established and widely used modality for cancer treatment. As cisplatin and its derivative carboplatin induce intrastrand and interstrand crosslinks (Deans \& West 2011), BRCA-deficient, hence ICL repair-deficient, HBOC cells are naturally sensitive to these drugs (De Picciotto et al. 2016). Indeed, BRCAmutated HBOC patients appear to have a better shortterm prognosis compared with non-BRCA patients, perhaps owing to the better response to chemotherapy (Konstantinopoulos et al. 2015), though this may not be the case for long-term survival (McLaughlin et al. 2013). Based on the discovery that PARP inhibition induces a dramatic cell killing in cells deficient in HR (Bryant et al. 2005, Farmer et al. 2005), an exciting opportunity to develop novel chemotherapeutic drugs has emerged. This is an instance where two distinct but important DNA repair activities are simultaneously inhibited, leading to cell death (synthetic lethality). An initial explanation that this lethality was due to impaired base excision repair, with an increased level of single-strand breaks that are converted to toxic DSBs by replication, is now challenged, and revised models have been proposed (Helleday 2011, Konstantinopoulos et al. 2015).

Resistance to chemotherapy drugs invariably appears after the initial clinical response during prolonged treatment. A number of resistance mechanisms have been proposed. It has been suggested that secondary mutations in $B R C A$ genes that restore the wild-type reading frame, leading to recovered HR activity, are the major mechanisms for the acquired resistance (Edwards et al. 2008, Sakai et al. 2008). This is analogous to the reversion mosaicism in hematopoietic cells sometimes observed in FA patients, which may mitigate progression of bone marrow failure (Soulier et al. 2005). Genome instability due to HR defects and selection may contribute to these phenomena. Another mechanism for acquired resistance in BRCA2-deficient tumors is the increased replication fork stability without restoring HR (Chaudhuri et al. 2016). This could be due to several mechanisms including PTIP deficiency that inhibits the access of MRE11 nuclease to stalled replication forks (Chaudhuri et al. 2016) or loss of the nucleosome remodeling factor CHD4 (Guillemette et al. 2015). In BRCA1-mutated tumors, normal levels of HR activities might be restored by the loss of $53 B P 1$ or REV7/MAD2L2 (Bouwman et al. 2010, Boersma et al. 2015, $\mathrm{Xu}$ et al. 2015). In the absence of BRCA1, these genes function to prevent end resection of DSBs, blocking the subsequent $\mathrm{HR}$ reaction.

$B R C A$-deficient tumors may accumulate an enormous number of mutations due to HR defects and genome instability during the carcinogenic process. Thus, these cells may carry higher numbers of tumor-specific peptide antigens that are presented to tumor-infiltrating lymphocytes. This hypothesis has been tested in clinical samples, leading to the conclusion that BRCA1/2-mutated high-grade serous ovarian cancer may be more sensitive to recently developed immune checkpoint inhibitors, such as anti-PD-1 or anti-PD-L1 antibodies (Strickland et al. 2016).

\section{How defects in HR and ICL repair affect hematopoietic stem cells or promote cancer development?}

Deficiencies in DNA repair limit the renewal capacity of aging hematopoietic stem cells (Rossi et al. 2007), and FA patients have higher levels of DNA damage in
(C) 2016 Society for Endocrinology Printed in Great Britain
Published by Bioscientifica Ltd 
these cells, leading to the upregulation of p53 and cell death/senescence (Ceccaldi et al. 2012). The origin of the endogenous damage in FA is an important issue that needs to be resolved (Garaycoechea \& Patel 2014) because this knowledge may allow us to develop a novel strategy for preventing bone marrow failure and cancer. Likewise, it is important to know by what mechanism the genome is destabilized in BRCA mutation carriers.

Endogenous aldehydes and lipid peroxidation products have been proposed as major sources of spontaneous DNA damage in FA (Garaycoechea et al. 2012). Using a mutant cell panel derived from the chicken DT40 cell line, it was shown that cells lacking Fancd2 or $\mathrm{Brca} 2$ are particularly sensitive to formaldehyde at concentrations similar to those in normal human serum (Ridpath et al. 2007). Patel and coworkers indicated in a series of papers that aldehyde detoxifying enzymes ALDH2 (which mainly catalyzes acetaldehyde) and ADH5 (which mainly catalyzes formaldehyde) play critical roles in FA model mice in the suppression of bone marrow failure and leukemogenesis (Langevin et al. 2011, Garaycoechea et al. 2012, Oberbeck et al. 2014, Pontel et al. 2015). These results clearly indicate that endogenous aldehydes can damage DNA in hematopoietic stem cells. As East Asians often carry an enzymatically defective $A L D H 2$ variant allele $(A L D H 2 * 2)$, we examined $A L D H 2$ genotypes in our cohort of Japanese FA patients (Hira et al. 2013). In line with the mouse studies, our results indicated that the $A L D H 2$ variant allele accelerates the progression of bone marrow failure in these patients. Strikingly, we identified several FA children who had homozygous ALDH2 mutations. These patients displayed particularly grave symptoms, including an extremely early onset of myelodysplasia (Hira et al. 2013, Yabe et al. 2016). This combined FA-ALDH2 deficiency could be considered to be a distinct disease entity. It will be exciting to see whether $A L D H 2$ can be a drug target to prevent bone marrow failure in FA patients. A compound that stimulates ALDH2 activity has already been developed (Perez-Miller et al. 2010). It will also be interesting to test how $A L D H 2$ status can affect cancer development in HBOC among East Asian populations.

Another source of DNA damage can be DNA replication fork stalling, which likely contributes to genome instability in FA or HBOC. The nascent DNA strand at the blocked fork is protected by RAD51 filaments stabilized by the C-terminal domain of BRCA2 in a manner independent of HR (Schlacher et al. 2011). In the absence of BRCA2, BRCA1 or FANCD2, the stalled fork cannot be protected and is degraded by MRE11 nuclease, leading to the loss of genetic information or genome rearrangements (Schlacher et al. 2012). This mechanism might be important for genome stability and tumor suppression provided by BRCA1/2 or FA genes.

Genes involved in pre-mRNA splicing and in the biogenesis and export of messenger ribonucleoprotein (mRNP) also have an important role for genome stability (Paulsen et al. 2009). R-loops consisting of DNA-RNA hybrids and a displaced single-stranded DNA often arise when transcription is perturbed (e.g., upon collision of transcription bubbles and replication forks). Thus, R-loops may be a chief source of replication stress and cancer-associated genome instability. Bhatia and coworkers demonstrated the accumulation of R-loops in BRCA2-depleted cells (Bhatia et al. 2015). Furthermore, recent studies asked whether the FA pathway coordinates transcription-replication conflicts and is involved in R-loop resolution (García-Rubio et al. 2015, Schwab et al. 2015). Indeed, human and mouse cells deficient in FA gene function accumulate R-loops, indicating that the FA pathway does play a critical role in R-loop resolution. MMC-induced FANCD2 foci levels are reduced by the expression of RNaseH1, which digests RNA in RNA-DNA hybrids. These studies imply that the accumulation of R-loops might contribute to hematopoietic stem cell exhaustion in FA. It will also be interesting to know how R-loops trigger the activation of the FA pathway.

Of note, it has also been proposed that cytokines that are upregulated in FA, such as TNF- $\alpha$ or TGF- $\beta$, may directly harm hematopoietic stem cells or modulate DNA damage repair in the stem cell compartment (Du et al. 2014, Zhang et al. 2016). This line of investigation may inform the development of novel therapeutic strategies for FA.

\section{Conclusions}

As summarized in this review, there has been a lot of progress toward the mechanistic understanding of HR repair and genome stability in this decade. Furthermore, we have seen an exciting development of PARP inhibitors as novel and promising cancer therapeutics. Detailed knowledge about the pathogenesis of HBOC and FA has been obtained.

Despite this progress, obvious questions are still lingering in the field. It is a true enigma that HR deficiency leads to carcinogenesis in a tissue-specific manner, although such specificity is also often the case for the other 
hereditary cancer syndromes. From a practical point of view, a large number of variants of unknown significance (VUS) generated from genetic testing of BRCA1 or BRCA2 pose a significant problem in the interpretation of the test results. In the long run, accumulated knowledge about segregation of the genotype and an individual's cancer susceptibility within families may eventually clarify the significance of VUS. At the moment, careful evaluation of DNA repair capacity in lymphocytes from cases with VUS might be useful (Pathania et al. 2014, Vaclová et al. 2015). It would be particularly useful to construct a collection of isogenic knock-in cells with candidate variants using the CRISPR-CAS9 system (Paquet et al. 2016). Endogenous aldehydes may include at least several molecular species (Xie et al. 2016), and they may induce various types of DNA damage, such as monoadducts, interstrand crosslinks or DNA-protein crosslinks. Which of these actually contributes to FA pathology, and how endogenous aldehydes are generated in cells should be elucidated in the near future.

\section{Declaration of interest}

The authors declare that there is no conflict of interest that could be perceived as prejudicing the impartiality of this review.

\section{Funding}

Our work is supported by grants from The Ministry of Education, Culture, Sports, Science and Technology (MEXT), a Grant-in-Aid for Scientific Research (KAKENHI) (KAKENHI Grant Numbers 23114010, 24310042, 26550026 and $15 \mathrm{H} 01738$ ) and grants from the Ministry of Health, Labour and Welfare.

\section{Acknowledgements}

The authors would like to thank our collaborators and past and current members of our laboratory for their contribution, and Prof. James Hejna (Graduate School of Biostudies, Kyoto University) for critical reading and English editing of the manuscript.

\section{References}

Alter BP 2014 Fanconi anemia and the development of leukemia. Best Practice \& Research. Clinical Haematology 27 214-221. (doi:10.1016/ j.beha.2014.10.002)

Ameziane N, May P, Haitjema A, van de Vrugt HJ, van Rossum-Fikkert SE, Ristic D, Williams GJ, Balk J, Rockx D, Li H, et al. 2015 A novel Fanconi anaemia subtype associated with a dominant-negative mutation in RAD51. Nature Communications 6 8829. (doi:10.1038/ncomms9829)

Auerbach AD 2009 Fanconi anemia and its diagnosis. Mutation Research 668 4-10. (doi:10.1016/j.mrfmmm.2009.01.013)

Ayoub N, Rajendra E, Su X, Jeyasekharan AD, Mahen R \& Venkitaraman AR 2009 The carboxyl terminus of Brca2 links the disassembly of Rad51 complexes to mitotic entry. Current Biology 19 1075-1085. (doi:10.1016/j.cub.2009.05.057)
Berwick M, Satagopan JM, Ben-Porat L, Carlson A, Mah K, Henry R, Diotti R, Milton K, Pujara K, Landers T, et al. 2007 Genetic heterogeneity among Fanconi anemia heterozygotes and risk of cancer. Cancer Research 67 9591-9596. (doi:10.1158/0008-5472.CAN-07-1501)

Bhatia V, Barroso SI, García-Rubio ML, Tumini E, Herrera-Moyano E \& Aguilera A 2015 BRCA2 prevents R-loop accumulation and associates with TREX-2 mRNA export factor PCID2. Nature 511 362-365. (doi:10.1038/nature13374)

Boersma V, Moatti N, Segura-Bayona S, Peuscher MH, van der Torre J, Wevers BA, Orthwein A, Durocher D \& Jacobs JJL 2015 MAD2L2 controls DNA repair at telomeres and DNA breaks by inhibiting 5 end resection. Nature 521 537-540. (doi:10.1038/nature14216)

Bogliolo M \& Surrallés J 2015 Fanconi anemia: a model disease for studies on human genetics and advanced therapeutics. Current Opinion in Genetics \& Development 33 32-40. (doi:10.1016/j. gde.2015.07.002)

Bogliolo M, Schuster B, Stoepker C, Derkunt B, Su Y, Raams A, Trujillo JP, Minguillón J, Ramírez MJ, Pujol R, et al. 2013 Mutations in ERCC4, encoding the DNA-repair endonuclease XPF cause Fanconi anemia. American Journal of Human Genetics 92 800-806. (doi:10.1016/j.ajhg.2013.04.002)

Bouwman P, Aly A, Escandell JM, Pieterse M, Bartkova J, van der Gulden H, Hiddingh S, Thanasoula M, Kulkarni A, Yang Q, et al. 2010 53BP1 loss rescues BRCA1 deficiency and is associated with triple-negative and BRCA-mutated breast cancers. Nature Structural \& Molecular Biology 17 688-695. (doi:10.1038/nsmb.1831)

Bryant HE, Schultz N, Thomas HD, Parker KM, Flower D, Lopez E, Kyle S, Meuth M, Curtin NJ \& Helleday T 2005 Specific killing of BRCA2-deficient tumours with inhibitors of poly(ADP-ribose) polymerase. Nature 434 913-917. (doi:10.1038/nature03443)

Buisson R, Dion-Côté A-M, Coulombe Y, Launay H, Cai H, Stasiak AZ, Stasiak A, Xia B \& Masson J-Y 2010 Cooperation of breast cancer proteins PALB2 and piccolo BRCA2 in stimulating homologous recombination. Nature Structural \& Molecular Biology 17 1247-1254. (doi:10.1038/nsmb.1915)

Cancer Genome Atlas Research Network 2011 Integrated genomic analyses of ovarian carcinoma. Nature 474 609-615. (doi:10.1038/ nature10166)

Carreira A \& Kowalczykowski SC 2011 Two classes of BRC repeats in BRCA2 promote RAD51 nucleoprotein filament function by distinct mechanisms. PNAS 108 10448-10453. (doi:10.1073/pnas.1106971108)

Carreira A, Hilario J, Amitani I, Baskin RJ, Shivji MKK, Venkitaraman AR \& Kowalczykowski SC 2009 The BRC repeats of BRCA2 modulate the DNA-binding selectivity of RAD51. Cell 136 1032-1043. (doi:10.1016/j.cell.2009.02.019)

Castellà M, Jacquemont C, Thompson EL, Yeo JE, Cheung RS, Huang J-W, Sobeck A, Hendrickson EA \& Taniguchi T 2015 FANCI regulates recruitment of the FA core complex at sites of DNA damage independently of FANCD2. PLoS Genetics 11 e1005563. (doi:10.1371/ journal.pgen.1005563)

Ceccaldi R, Parmar K, Mouly E, Delord M, Kim JM, Regairaz M, Pla M, Vasquez N, Zhang Q-S, Pondarre C, et al. 2012 Bone marrow failure in Fanconi anemia is triggered by an exacerbated p53/p21 DNA damage response that impairs hematopoietic stem and progenitor cells. Cell Stem Cell 11 36-49. (doi:10.1016/j.stem.2012.05.013)

Ceccaldi R, Sarangi P \& D'Andrea AD 2016 The Fanconi anaemia pathway: new players and new functions. Nature Reviews Molecular Cell Biology 17 337-349. (doi:10.1038/nrm.2016.48)

Chapman JR, Taylor MRG \& Boulton SJ 2012 Playing the end game: DNA double-strand break repair pathway choice. Molecular Cell 47 497-510. (doi:10.1016/j.molcel.2012.07.029)

Chapman JR, Barral P, Vannier J-B, Borel V, Steger M, Tomas-Loba A, Sartori AA, Adams IR, Batista FD \& Boulton SJ 2013 RIF1 is essential for 53BP1-dependent nonhomologous end joining and suppression of DNA double-strand break resection. Molecular Cell 49 858-871. (doi:10.1016/j.molcel.2013.01.002) 
Chaudhuri AR, Callen E, Ding X, Gogola E, Duarte AA, Lee J-E, Wong N, Lafarga V, Calvo JA, Panzarino NJ, et al. 2016 Replication fork stability confers chemoresistance in BRCA-deficient cells. Nature $\mathbf{5 3 5}$ 382-387. (doi:10.1038/nature18325)

Chen Y-H, Jones MJK, Yin Y, Crist SB, Colnaghi L, Sims RJ, Rothenberg E, Jallepalli PV \& Huang TT 2015 ATR-mediated phosphorylation of FANCI regulates dormant origin firing in response to replication stress. Molecular Cell 58 323-338. (doi:10.1016/j.molcel.2015.02.031)

Collins NB, Wilson JB, Bush T, Thomashevski A, Roberts KJ, Jones NJ \& Kupfer GM 2009 ATR-dependent phosphorylation of FANCA on serine 1449 after DNA damage is important for FA pathway function. Blood 113 2181-2190. (doi:10.1182/blood-2008-05154294)

Connor F, Bertwistle D, Mee PJ, Ross GM, Swift S, Grigorieva E, Tybulewicz VL \& Ashworth A 1997 Tumorigenesis and a DNA repair defect in mice with a truncating Brca2 mutation. Nature Genetics 17 423-430. (doi:10.1038/ng1297-423)

Cousineau I \& Belmaaza A 2011 EMSY overexpression disrupts the BRCA2/RAD51 pathway in the DNA-damage response: implications for chromosomal instability/recombination syndromes as checkpoint diseases. Molecular Genetics and Genomics 285 325-340. (doi:10.1007/ s00438-011-0612-5)

De Picciotto N, Cacheux W, Roth A, Chappuis PO \& Labidi-Galy SI 2016 Ovarian cancer: status of homologous recombination pathway as a predictor of drug response. Critical Reviews in Oncology/Hematology 101 50-59. (doi:10.1016/j.critrevonc.2016.02.014)

Deans AJ \& West SC 2011 DNA interstrand crosslink repair and cancer. Nature Reviews Cancer 11 467-480. (doi:10.1038/nrc3088)

Debatisse M, Le Tallec B, Letessier A, Dutrillaux B \& Brison O 2012 Common fragile sites: mechanisms of instability revisited. Trends in Genetics 28 22-32. (doi:10.1016/j.tig.2011.10.003)

Domchek SM, Tang J, Stopfer J, Lilli DR, Hamel N, Tischkowitz M, Monteiro ANA, Messick TE, Powers J, Yonker A, et al. 2013 Biallelic deleterious BRCA1 mutations in a woman with early-onset ovarian cancer. Cancer Discovery 3 399-405. (doi:10.1158/2159-8290. CD-12-0421)

Du W, Erden O \& Pang Q 2014 TNF- $\alpha$ signaling in Fanconi anemia. Blood Cells, Molecules \& Diseases 52 2-11. (doi:10.1016/j. bcmd.2013.06.005)

Duro E, Lundin C, Ask K, Sanchez-Pulido L, MacArtney TJ, Toth R, Ponting CP, Groth A, Helleday T \& Rouse J 2010 Identification of the MMS22L-TONSL complex that promotes homologous recombination. Molecular Cell 40 632-644. (doi:10.1016/j.molcel.2010.10.023)

Duxin JP \& Walter JC 2015 What is the DNA repair defect underlying Fanconi anemia? Current Opinion in Cell Biology 37 49-60. (doi:10.1016/j.ceb.2015.09.002)

Edwards SL, Brough R, Lord CJ, Natrajan R, Vatcheva R, Levine DA, Boyd J, Reis-Filho JS \& Ashworth A 2008 Resistance to therapy caused by intragenic deletion in BRCA2. Nature 451 1111-1115. (doi:10.1038/nature06548)

Esashi F, Christ N, Gannon J, Liu Y, Hunt T, Jasin M \& West SC 2005 CDK-dependent phosphorylation of BRCA2 as a regulatory mechanism for recombinational repair. Nature 434 598-604. (doi:10.1038/nature03404)

Esashi F, Galkin VE, Yu X, Egelman EH \& West SC 2007 Stabilization of RAD51 nucleoprotein filaments by the C-terminal region of BRCA2. Nature Structural \& Molecular Biology 14 468-474. (doi:10.1038/ nsmb1245)

Escribano-Diaz C, Orthwein A, Fradet-Turcotte A, Xing M, Young JTF, Tká010D J, Cook MA, Rosebrock AP, Munro M, Canny MD, et al. 2013 A cell cycle-dependent regulatory circuit composed of 53BP1-RIF1 and BRCA1-CtIP controls DNA repair pathway choice. Molecular Cell 49 872-883. (doi:10.1016/j.molcel.2013.01.001)

Farmer H, McCabe N, Lord CJ, Tutt ANJ, Johnson DA, Richardson TB, Santarosa M, Dillon KJ, Hickson I, Knights C, et al. 2005 Targeting the DNA repair defect in BRCA mutant cells as a therapeutic strategy. Nature 434 917-921. (doi:10.1038/nature03445)

Ferlay J, Soerjomataram I, Dikshit R, Eser S, Mathers C, Rebelo M, Parkin DM, Forman D \& Bray F 2015 Cancer incidence and mortality worldwide: sources, methods and major patterns in GLOBOCAN 2012. International Journal of Cancer 136 E359-E386. (doi:10.1002/ijc.29210)

Friedman LS, Thistlethwaite FC, Patel KJ, Yu VP, Lee H, Venkitaraman AR, Abel KJ, Carlton MB, Hunter SM, Colledge WH, et al. 1998 Thymic lymphomas in mice with a truncating mutation in Brca2. Cancer Research 58 1338-1343.

Garaycoechea JI \& Patel KJ 2014 Why does the bone marrow fail in Fanconi anemia? Blood 123 26-34. (doi:10.1182/blood-2013-09427740)

Garaycoechea JI, Crossan GP, Langevin F, Daly M, Arends MJ \& Patel K 2012 Genotoxic consequences of endogenous aldehydes on mouse haematopoietic stem cell function. Nature 489 571-575. (doi:10.1038/nature11368)

Garcia-Higuera I, Taniguchi T, Ganesan S, Meyn MS, Timmers C, Hejna J, Grompe M \& D'Andrea AD 2001 Interaction of the Fanconi anemia proteins and BRCA1 in a common pathway. Molecular Cell 7 249-262. (doi:10.1016/S1097-2765(01)00173-3)

García-Rubio ML, Pérez-Calero C, Barroso SI, Tumini E, Herrera-Moyano E, Rosado IV \& Aguilera A 2015 The Fanconi anemia pathway protects genome integrity from R-loops. PLoS Genetics 11 e1005674. (doi:10.1371/journal.pgen.1005674)

Garner E, Kim Y, Lach FP, Kottemann MC \& Smogorzewska A 2013 Human GEN1 and the SLX4-associated nucleases MUS81 and SLX1 are essential for the resolution of replication-induced Holliday junctions. Cell Reports 5 207-215. (doi:10.1016/j.celrep.2013.08.041)

Guillemette S, Serra RW, Peng M, Hayes JA, Konstantinopoulos PA, Green MR \& Cantor SB 2015 Resistance to therapy in BRCA2 mutant cells due to loss of the nucleosome remodeling factor CHD4. Genes \& Development 29 489-494. (doi:10.1101/gad.256214.114)

Hartikainen JM, Tengström M, Winqvist R, Jukkola-Vuorinen A, Pylkäs K, Kosma V-M, Soini Y \& Mannermaa A 2015 KEAP1 Genetic polymorphisms associate with breast cancer risk and survival outcomes. Clinical Cancer Research 21 1591-1601. (doi:10.1158/ 1078-0432.CCR-14-1887)

Hashimoto Y, Puddu F \& Costanzo V 2012 RAD51- and MRE11dependent reassembly of uncoupled CMG helicase complex at collapsed replication forks. Nature Structural \& Molecular Biology 19 17-24. (doi:10.1038/nsmb.2177)

Håkansson S, Johannsson O, Johansson U, Sellberg G, Loman N, Gerdes AM, Holmberg E, Dahl N, Pandis N, Kristoffersson U, et al. 1997 Moderate frequency of BRCA1 and BRCA2 germ-line mutations in Scandinavian familial breast cancer. American Journal of Human Genetics 60 1068-1078.

Helleday T 2011 The underlying mechanism for the PARP and BRCA synthetic lethality: clearing up the misunderstandings. Molecular Oncology 5 387-393. (doi:10.1016/j.molonc.2011.07.001)

Hira A, Yabe H, Yoshida K, Okuno Y, Shiraishi Y, Chiba K, Tanaka H, Miyano S, Nakamura J, Kojima S, et al. 2013 Variant ALDH2 is associated with accelerated progression of bone marrow failure in Japanese Fanconi anemia patients. Blood 122 3206-3209. (doi:10.1182/blood-2013-06-507962)

Hira A, Yoshida K, Sato K, Okuno Y, Shiraishi Y, Chiba K, Tanaka H, Miyano S, Shimamoto A, Tahara H, et al. 2015 Mutations in the gene encoding the E2 conjugating enzyme UBE2T cause Fanconi anemia. American Journal of Human Genetics 96 1001-1007. (doi:10.1016/j.ajhg.2015.04.022)

Hirsch B, Shimamura A, Moreau L, Baldinger S, Hag-alshiekh M, Bostrom B, Sencer S \& D'Andrea AD 2004 Association of biallelic BRCA2/FANCD1 mutations with spontaneous chromosomal instability and solid tumors of childhood. Blood 103 2554-2559. (doi:10.1182/blood-2003-06-1970) http://erc.endocrinology-journals.org

DOI: 10.1530/ERC-16-0221
(C) 2016 Society for Endocrinology Printed in Great Britain 
Hodskinson MRG, Silhan J, Crossan GP, Garaycoechea JI, Mukherjee S, Johnson CM, Schärer OD \& Patel KJ 2014 Mouse SLX4 is a tumor suppressor that stimulates the activity of the nuclease XPF-ERCC1 in DNA crosslink repair. Molecular Cell 54 472-484. (doi:10.1016/ j.molcel.2014.03.014)

Hoeijmakers JH 2001 Genome maintenance mechanisms for preventing cancer. Nature 411 366-374. (doi:10.1038/35077232)

Howlett NG, Taniguchi T, Olson S, Cox B, Waisfisz Q, De DieSmulders C, Persky N, Grompe M, Joenje H, Pals G, et al. 2002 Biallelic inactivation of BRCA2 in Fanconi anemia. Science 297 606-609. (doi:10.1126/science.1073834)

Huang M, Kim JM, Shiotani B, Yang K, Zou L \& D'Andrea AD 2010 The FANCM/FAAP24 complex is required for the DNA interstrand crosslink-induced checkpoint response. Molecular Cell 39 259-268. (doi:10.1016/j.molcel.2010.07.005)

Huang J, Liu S, Bellani MA, Thazhathveetil AK, Ling C, de Winter JP, Wang Y, Wang W \& Seidman MM 2013 The DNA translocase FANCM/ MHF promotes replication traverse of DNA interstrand crosslinks. Molecular Cell 52 434-446. (doi:10.1016/j.molcel.2013.09.021)

Hughes-Davies L, Huntsman D, Ruas M, Fuks F, Bye J, Chin S-F, Milner J, Brown LA, Hsu F, Gilks B, et al. 2003 EMSY links the BRCA2 pathway to sporadic breast and ovarian cancer. Cell 115 523-535. (doi:10.1016/S0092-8674(03)00930-9)

Ishiai M, Kitao H, Smogorzewska A, Tomida J, Kinomura A, Uchida E, Saberi A, Kinoshita E, Kinoshita-Kikuta E, Koike T, et al. 2008 FANCI phosphorylation functions as a molecular switch to turn on the Fanconi anemia pathway. Nature Structural \& Molecular Biology 15 1138-1146. (doi:10.1038/nsmb.1504)

Jensen RB, Carreira A \& Kowalczykowski SC 2010 Purified human BRCA2 stimulates RAD51-mediated recombination. Nature $\mathbf{4 6 7}$ 678-683. (doi:10.1038/nature09399)

Jeyasekharan AD, Liu Y, Hattori H, Pisupati V, Jonsdottir AB, Rajendra E, Lee M, Sundaramoorthy E, Schlachter S, Kaminski CF, et al. 2013 A cancer-associated BRCA2 mutation reveals masked nuclear export signals controlling localization. Nature Structural \& Molecular Biology 20 1191-1198. (doi:10.1038/nsmb.2666)

Jonkers J, Meuwissen R, van der Gulden H, Peterse H, van der Valk M \& Berns A 2001 Synergistic tumor suppressor activity of BRCA2 and p53 in a conditional mouse model for breast cancer. Nature Genetics 29 418-425. (doi:10.1038/ng747)

Joo W, Xu G, Persky NS, Smogorzewska A, Rudge DG, Buzovetsky O, Elledge SJ \& Pavletich NP 2011 Structure of the FANCI-FANCD2 complex: insights into the Fanconi anemia DNA repair pathway. Science 333 312-316. (doi:10.1126/science.1205805)

Kashiyama K, Nakazawa Y, Pilz DT, Guo C, Shimada M, Sasaki K, Fawcett H, Wing JF, Lewin SO, Carr L, et al. 2013 Malfunction of nuclease ERCC1-XPF results in diverse clinical manifestations and causes Cockayne syndrome, xeroderma pigmentosum, and Fanconi anemia. American Journal of Human Genetics 92 807-819. (doi:10.1016/j.ajhg.2013.04.007)

Kiiski JI, Pelttari LM, Khan S, Freysteinsdottir ES, Reynisdottir I, Hart SN, Shimelis H, Vilske S, Kallioniemi A, Schleutker J, et al. 2014 Exome sequencing identifies FANCM as a susceptibility gene for triple-negative breast cancer. PNAS 111 15172-15177. (doi:10.1073/ pnas.1407909111)

Kim JM, Kee Y, Gurtan A \& D'Andrea AD 2008 Cell cycle-dependent chromatin loading of the Fanconi anemia core complex by FANCM/ FAAP24. Blood 111 5215-5222. (doi:10.1182/blood-2007-09-113092)

Kim H, Yang K, Dejsuphong D \& D'Andrea AD 2012 Regulation of Rev1 by the Fanconi anemia core complex. Nature Structural \& Molecular Biology 19 164-170. (doi:10.1038/nsmb.2222)

Kim Y, Spitz GS, Veturi U, Lach FP, Auerbach AD \& Smogorzewska A 2013 Regulation of multiple DNA repair pathways by the Fanconi anemia protein SLX4. Blood 121 54-63. (doi:10.1182/blood-2012-07-441212)

King TA, Li W, Brogi E, Yee CJ, Gemignani ML, Olvera N, Levine DA, Norton L, Robson ME, Offit K, et al. 2007 Heterogenic loss of the wild-type BRCA allele in human breast tumorigenesis. Annals of Surgical Oncology 14 2510-2518. (doi:10.1245/s10434-007-9372-1)

Kitao H \& Takata M 2011 Fanconi anemia: a disorder defective in the DNA damage response. International Journal of Hematology 93 417-424. (doi:10.1007/s12185-011-0777-z)

Klein Douwel D, Boonen RACM, Long DT, Szypowska AA, Räschle M, Walter JC \& Knipscheer P 2014 XPF-ERCC1 acts in Unhooking DNA interstrand crosslinks in cooperation with FANCD2 and FANCP/ SLX4. Molecular Cell 54 460-471. (doi:10.1016/j.molcel.2014.03.015)

Knipscheer P, Räschle M, Smogorzewska A, Enoiu M, Ho TV, Schärer OD, Elledge SJ \& Walter JC 2009 The Fanconi anemia pathway promotes replication-dependent DNA interstrand cross-link repair. Science $\mathbf{3 2 6}$ 1698-1701. (doi:10.1126/science.1182372)

Knudson AG 1971 Mutation and cancer: statistical study of retinoblastoma. PNAS 68 820-823. (doi:10.1073/pnas.68.4.820)

Komori K, Hidaka M, Horiuchi T, Fujikane R, Shinagawa H \& Ishino Y 2004 Cooperation of the N-terminal helicase and C-terminal endonuclease activities of Archaeal Hef protein in processing stalled replication forks. Journal of Biological Chemistry 279 53175-53185. (doi:10.1074/jbc.M409243200)

Konstantinopoulos PA, Ceccaldi R, Shapiro GI \& D'Andrea AD 2015 Homologous recombination deficiency: exploiting the fundamental vulnerability of ovarian cancer. Cancer Discovery 5 1137-1154. (doi:10.1158/2159-8290.CD-15-0714)

Kottemann MC \& Smogorzewska A 2013 Fanconi anaemia and the repair of Watson and Crick DNA crosslinks. Nature 493 356-363. (doi:10.1038/nature11863)

Lachaud C, Castor D, Hain K, Muñoz I, Wilson J, MacArtney TJ, Schindler D \& Rouse J 2014 Distinct functional roles for the two SLX4 ubiquitin-binding UBZ domains mutated in Fanconi anemia. Journal of Cell Science 127 2811-2817. (doi:10.1242/jcs.146167)

Lachaud C, Moreno A, Marchesi F, Toth R, Blow JJ \& Rouse J 2016 Ubiquitinated Fancd2 recruits Fan1 to stalled replication forks to prevent genome instability. Science 351 846-849. (doi:10.1126/ science.aad5634)

Langevin F, Crossan GP, Rosado IV, Arends MJ \& Patel KJ 2011 Fancd 2 counteracts the toxic effects of naturally produced aldehydes in mice. Nature 475 53-58. (doi:10.1038/nature10192)

Liang C-C, Zhan B, Yoshikawa Y, Haas W, Gygi SP \& Cohn MA 2015 UHRF1 is a sensor for DNA interstrand crosslinks and recruits FANCD2 to initiate the Fanconi anemia pathway. Cell Reports 10 1947-1956. (doi:10.1016/j.celrep.2015.02.053)

Liang C-C, Li Z, Lopez-Martinez D, Nicholson WV, Vénien-Bryan C \& Cohn MA 2016 The FANCD2-FANCI complex is recruited to DNA interstrand crosslinks before monoubiquitination of FANCD2. Nature Communications 7 12124. (doi:10.1038/ncomms12124)

Lim ET, Würtz P, Havulinna AS, Palta P, Tukiainen T, Rehnström K, Esko T, Mägi R, Inouye M, Lappalainen T, et al. 2014 Distribution and medical impact of loss-of-function variants in the Finnish founder population. PLoS Genetics 10 e1004494. (doi:10.1371/journal.pgen.1004494)

Liu J, Doty T, Gibson B \& Heyer W-D 2010 Human BRCA2 protein promotes RAD51 filament formation on RPA-covered single-stranded DNA. Nature Structural \& Molecular Biology 17 1260-1262. (doi:10.1038/nsmb.1904)

Lobitz S \& Velleuer E 2006 Guido Fanconi (1892-1979): a jack of all trades. Nature Reviews. Cancer 6 893-898. (doi:10.1038/nrc2009)

Long DT, Räschle M, Joukov V \& Walter JC 2011 Mechanism of RAD51-dependent DNA interstrand cross-link repair. Science $\mathbf{3 3 3}$ 84-87. (doi:10.1126/science.1204258)

Lossaint G, Larroque M, Ribeyre C, Bec N, Larroque C, Décaillet C, Gari K \& Constantinou A 2013 FANCD2 binds MCM proteins and controls replisome function upon activation of s phase checkpoint signaling. Molecular Cell 51 678-690. (doi:10.1016/j.molcel.2013.07.023)

Ludwig T, Chapman DL, Papaioannou VE \& Efstratiadis A 1997 Targeted mutations of breast cancer susceptibility gene homologs in mice: lethal phenotypes of Brca1, Brca2, Brca1/Brca2, Brca1/p53, and 
Brca2/p53 nullizygous embryos. Genes \& Development 11 1226-1241. (doi:10.1101/gad.11.10.1226)

Masson JY, Tarsounas MC, Stasiak AZ, Stasiak A, Shah R, Mcllwraith MJ, Benson FE \& West SC 2001 Identification and purification of two distinct complexes containing the five RAD51 paralogs. Genes \& Development 15 3296-3307. (doi:10.1101/gad.947001)

Matsushita N, Kitao H, Ishiai M, Nagashima N, Hirano S, Okawa K, Ohta T, Yu DS, McHugh PJ, Hickson ID, et al. 2005 A FancD2monoubiquitin fusion reveals hidden functions of Fanconi anemia core complex in DNA repair. Molecular Cell 19 841-847. (doi:10.1016/j.molcel.2005.08.018)

McLaughlin JR, Rosen B, Moody J, Pal T, Fan I, Shaw PA, Risch HA, Sellers TA, Sun P \& Narod SA 2013 Long-term ovarian cancer survival associated with mutation in BRCA1 or BRCA2. Journal of the National Cancer Institute 105 141-148. (doi:10.1093/jnci/djs494)

Meetei AR, Medhurst AL, Ling C, Xue Y, Singh TR, Bier P, Steltenpool J, Stone S, Dokal I, Mathew CG, et al. 2005 A human ortholog of archaeal DNA repair protein Hef is defective in Fanconi anemia complementation group M. Nature Genetics 37 958-963. (doi:10.1038/ng1626)

Menzel T, Nähse-Kumpf V, Kousholt AN, Klein DK, Lund-Andersen C, Lees M, Johansen JV, Syljuåsen RG \& Sørensen CS 2011 A genetic screen identifies BRCA2 and PALB2 as key regulators of G2 checkpoint maintenance. EMBO Reports 12 705-712. (doi:10.1038/embor.2011.99)

Miki Y, Swensen J, Shattuck-Eidens D, Futreal P, Harshman K, Tavtigian S, Liu Q, Cochran C, Bennett L, Ding W, et al. 1994 A strong candidate for the breast and ovarian cancer susceptibility gene BRCA1. Science 266 66-71. (doi:10.1126/science.7545954)

Murina O, Aesch von C, Karakus U, Ferretti LP, Bolck HA, Hänggi K \& Sartori AA 2014 FANCD2 and CtIP cooperate to repair DNA interstrand crosslinks. Cell Reports 7 1030-1038. (doi:10.1016/j.celrep.2014.03.069)

Murzin AG 1993 OB(oligonucleotide/oligosaccharide binding)-fold: common structural and functional solution for non-homologous sequences. EMBO Journal 12 861-867.

Nakanishi K, Yang Y-G, Pierce AJ, Taniguchi T, Digweed M, D'Andrea AD, Wang Z-Q \& Jasin M 2005 Human Fanconi anemia monoubiquitination pathway promotes homologous DNA repair. PNAS 102 1110-1115. (doi:10.1073/pnas.0407796102)

Nielsen FC \& van Overeem Hansen T 2016 Hereditary breast and ovarian cancer: new genes in confined pathways. Nature Reviews Cancer 16 599-612. (doi:10.1038/nrc.2016.72)

Nik-Zainal S, Davies H, Staaf J, Ramakrishna M, Glodzik D, Zou X, Martincorena I, Alexandrov LB, Martin S, Wedge DC, et al. 2016 Landscape of somatic mutations in 560 breast cancer whole-genome sequences. Nature 534 47-54. (doi:10.1038/nature17676)

O'Donnell L, Panier S, Wildenhain J, Tkach JM, Al-Hakim A, Landry M-C, Escribano-Diaz C, Szilard RK, Young JTF, Munro M, et al. 2010 The MMS22L-TONSL complex mediates recovery from replication stress and homologous recombination. Molecular Cell $\mathbf{4 0}$ 619-631. (doi:10.1016/j.molcel.2010.10.024)

Oberbeck N, Langevin F, King G, de Wind N, Crossan GP \& Patel KJ 2014 Maternal aldehyde elimination during pregnancy preserves the fetal genome. Molecular Cell 55 807-817. (doi:10.1016/ j.molcel.2014.07.010)

Orthwein A, Noordermeer SM, Wilson MD, Landry S, Enchev RI, Sherker A, Munro M, Pinder J, Salsman J, Dellaire G, et al. 2015 A mechanism for the suppression of homologous recombination in G1 cells. Nature 528 422-426. (doi:10.1038/nature16142)

Paquet D, Kwart D, Chen A, Sproul A, Jacob S, Teo S, Olsen KM, Gregg A, Noggle S \& Tessier-Lavigne M 2016 Efficient introduction of specific homozygous and heterozygous mutations using CRISPR/ Cas9. Nature 533 125-129. (doi:10.1038/nature17664)

Patel KJ, Yu VP, Lee H, Corcoran A, Thistlethwaite FC, Evans MJ, Colledge WH, Friedman LS, Ponder BA \& Venkitaraman AR 1998 Involvement of Brca2 in DNA repair. Molecular Cell 1 347-357. (doi:10.1016/S1097-2765(00)80035-0)
Pathania S, Bade S, Le Guillou M, Burke K, Reed R, Bowman-Colin C, Su Y, Ting DT, Polyak K, Richardson AL, et al. 2014 BRCA1 haploinsufficiency for replication stress suppression in primary cells. Nature Communications 5 5496. (doi:10.1038/ncomms6496)

Paulsen RD, Soni DV, Wollman R, Hahn AT, Yee M-C, Guan A, Hesley JA, Miller SC, Cromwell EF, Solow-Cordero DE, et al. 2009 A genome-wide siRNA screen reveals diverse cellular processes and pathways that mediate genome stability. Molecular Cell 35 228-239. (doi:10.1016/j.molcel.2009.06.021)

Pellegrini L, Yu DS, Lo T, Anand S, Lee M, Blundell TL \& Venkitaraman AR 2002 Insights into DNA recombination from the structure of a RAD51-BRCA2 complex. Nature 420 287-293. (doi:10.1038/nature01230)

Perez-Miller S, Younus H, Vanam R, Chen C-H, Mochly-Rosen D \& Hurley TD 2010 Alda-1 is an agonist and chemical chaperone for the common human aldehyde dehydrogenase 2 variant. Nature Structural \& Molecular Biology 17 159-164. (doi:10.1038/nsmb.1737)

Peterlongo P, Catucci I, Colombo M, Caleca L, Mucaki E, Bogliolo M, Marín M, Damiola F, Bernard L, Pensotti V, et al. 2015 FANCM c.5791C $>$ T nonsense mutation (rs144567652) induces exon skipping, affects DNA repair activity and is a familial breast cancer risk factor. Human Molecular Genetics 24 5345-5355. (doi:10.1093/hmg/ddv251)

Pontel LB, Rosado IV, Burgos-Barragan G, Garaycoechea JI, Yu R, Arends MJ, Chandrasekaran G, Broecker V, Wei W, Liu L, et al. 2015 Endogenous formaldehyde is a hematopoietic stem cell genotoxin and metabolic carcinogen. Molecular Cell 60 177-188. (doi:10.1016/ j.molcel.2015.08.020)

Prakash R, Zhang Y, Feng W \& Jasin M 2015 Homologous recombination and human health: the roles of BRCA1, BRCA2, and associated proteins. Cold Spring Harbor Perspectives in Biology $\mathbf{7}$ a016600. (doi:10.1101/cshperspect.a016600)

Räschle M, Knipsheer P, Enoiu M, Angelov T, Sun J, Griffith JD, Ellenberger TE, Schärer OD \& Walter JC 2008 Mechanism of replication-coupled DNA interstrand crosslink repair. Cell $\mathbf{1 3 4}$ 969-980. (doi:10.1016/j.cell.2008.08.030)

Reid S, Schindler D, Hanenberg H, Barker K, Hanks S, Kalb R, Neveling K, Kelly P, Seal S, Freund M, et al. 2007 Biallelic mutations in PALB2 cause Fanconi anemia subtype FA-N and predispose to childhood cancer. Nature Genetics 39 162-164. (doi:10.1038/ng1947)

Rickman KA, Lach FP, Abhyankar A, Donovan FX, Sanborn EM, Kennedy JA, Sougnez C, Gabriel SB, Elemento O, Chandrasekharappa SC, et al. 2015 Deficiency of UBE2T, the E2 ubiquitin ligase necessary for FANCD2 and FANCI ubiquitination, causes FA-T subtype of Fanconi anemia. Cell Reports 12 35-41. (doi:10.1016/j.celrep.2015.06.014)

Ridpath JR, Nakamura A, Tano K, Luke AM, Sonoda E, Arakawa H, Buerstedde J-M, Gillespie DAF, Sale JE, Yamazoe M, et al. 2007 Cells deficient in the FANC/BRCA pathway are hypersensitive to plasma levels of formaldehyde. Cancer Research 67 11117-11122. (doi:10.1158/0008-5472.CAN-07-3028)

Rossi DJ, Bryder D, Seita J, Nussenzweig A, Hoeijmakers J \& Weissman IL 2007 Deficiencies in DNA damage repair limit the function of haematopoietic stem cells with age. Nature 447 725-729. (doi:10.1038/nature05862)

Rouet P, Smih F \& Jasin M 1994 Expression of a site-specific endonuclease stimulates homologous recombination in mammalian cells. PNAS 91 6064-6068. (doi:10.1073/pnas.91.13.6064)

Roy R, Chun J \& Powell SN 2011 BRCA1 and BRCA2: different roles in a common pathway of genome protection. Nature Reviews Cancer 12 68-78. (doi:10.1038/nrc3181)

Saeki H, Siaud N, Christ N, Wiegant WW, van Buul PPW, Han M, Zdzienicka MZ, Stark JM \& Jasin M 2006 Suppression of the DNA repair defects of BRCA2-deficient cells with heterologous protein fusions. PNAS 103 8768-8773. (doi:10.1073/pnas.0600298103)

Sakai W, Swisher EM, Karlan BY, Agarwal MK, Higgins J, Friedman C, Villegas E, Jacquemont C, Farrugia DJ, Couch FJ, et al. 2008 Secondary 
mutations as a mechanism of cisplatin resistance in BRCA2-mutated cancers. Nature 451 1116-1120. (doi:10.1038/nature06633)

Sarbajna S \& West SC 2014 Holliday junction processing enzymes as guardians of genome stability. Trends in Biochemical Sciences 39 409-419. (doi:10.1016/j.tibs.2014.07.003)

Sasaki MS \& Tonomura A 1973 A high susceptibility of Fanconi's anemia to chromosome breakage by DNA cross-linking agents. Cancer Research 33 1829-1836.

Sato K, Ishiai M, Toda K, Furukoshi S, Osakabe A, Tachiwana H, Takizawa Y, Kagawa W, Kitao H, Dohmae N, et al. 2012 Histone chaperone activity of Fanconi anemia proteins, FANCD2 and FANCI, is required for DNA crosslink repair. EMBO Journal 31 3524-3536. (doi:10.1038/emboj.2012.197)

Sawyer SL, Tian L, Kahkonen M, Schwartzentruber J, Kircher M, University of Washington Centre for Mendelian Genomics, FORGE Canada Consortium, Majewski J, Dyment DA, Innes AM, et al. 2015 Biallelic mutations in BRCA1 cause a new Fanconi anemia subtype. Cancer Discovery 5 135-142. (doi:10.1158/2159-8290. CD-14-1156)

Schlacher K, Christ N, Siaud N, Egashira A, Wu H \& Jasin M 2011 Double-strand break repair-independent role for BRCA2 in blocking stalled replication fork degradation by MRE11. Cell 145 529-542. (doi:10.1016/j.cell.2011.03.041)

Schlacher K, Wu H \& Jasin M 2012 A distinct replication fork protection pathway connects Fanconi anemia tumor suppressors to RAD51BRCA1/2. Cancer Cell 22 106-116. (doi:10.1016/j.ccr.2012.05.015)

Schroeder TM, Anschütz F \& Knopp A 1964 [Spontaneous chromosome aberrations in familial panmyelopathy]. Humangenetik 1 194-196.

Schwab RA, Nieminuszczy J, Shah F, Langton J, Martinez DL, Liang C-C, Cohn MA, Gibbons RJ, Deans AJ \& Niedzwiedz W 2015 The Fanconi anemia pathway maintains genome stability by coordinating replication and transcription. Molecular Cell 60 351-361. (doi:10.1016/j.molcel.2015.09.012)

Seal S, Barfoot R, Jayatilake H, Smith P, Renwick A, Bascombe L, McGuffog L, Evans DG, Eccles D, Easton DF, et al. 2003 Evaluation of Fanconi anemia genes in familial breast cancer predisposition. Cancer Research 63 8596-8599.

Shahid T, Soroka J, Kong EH, Malivert L, Mcilwraith MJ, Pape T, West SC \& Zhang X 2014 Structure and mechanism of action of the BRCA2 breast cancer tumor suppressor. Nature Structural \& Molecular Biology 21 962-968. (doi:10.1038/nsmb.2899)

Shamseldin HE, Elfaki M \& Alkuraya FS 2012 Exome sequencing reveals a novel Fanconi group defined by XRCC2 mutation. Journal of Medical Genetics 49 184-186. (doi:10.1136/jmedgenet-2011-100585)

Shivji MKK, Mukund SR, Rajendra E, Chen S, Short JM, Savill J, Klenerman D \& Venkitaraman AR 2009 The BRC repeats of human BRCA2 differentially regulate RAD51 binding on single- versus double-stranded DNA to stimulate strand exchange. PNAS 106 13254-13259. (doi:10.1073/pnas.0906208106)

Singh TR, Bakker ST, Agarwal S, Jansen M, Grassman E, Godthelp BC, Ali AM, Du C-H, Rooimans MA, Fan Q, et al. 2009 Impaired FANCD2 monoubiquitination and hypersensitivity to camptothecin uniquely characterize Fanconi anemia complementation group M. Blood 114 174-180. (doi:10.1182/blood-2009-02-207811)

Singh TR, Ali AM, Paramasivam M, Pradhan A, Wahengbam K, Seidman MM \& Meetei AR 2013 ATR-dependent phosphorylation of FANCM at serine 1045 is essential for FANCM functions. Cancer Research 73 4300-4310. (doi:10.1158/0008-5472.CAN-12-3976)

Smogorzewska A, Matsuoka S, Vinciguerra P, McDonald ER, Hurov KE, Luo J, Ballif BA, Gygi SP, Hofmann K, D'Andrea AD, et al. 2007 Identification of the FANCI protein, a monoubiquitinated FANCD2 paralog required for DNA repair. Cell 129 289-301. (doi:10.1016/ j.cell.2007.03.009)

Sonoda E, Sasaki MS, Buerstedde J-M, Bezzubova O, Shinohara A, Ogawa H, Takata M, Yamaguchi-Iwai Y \& Takeda S 1998 Rad51-deficient vertebrate cells accumulate chromosomal breaks prior to cell death. EMBO Journal 17 598-608. (doi:10.1093/ emboj/17.2.598)

Soulier J, Leblanc T, Larghero J, Dastot H, Shimamura A, Guardiola P, Esperou H, Ferry C, Jubert C, Feugeas J-P, et al. 2005 Detection of somatic mosaicism and classification of Fanconi anemia patients by analysis of the FA/BRCA pathway. Blood 105 1329-1336. (doi:10.1182/blood-2004-05-1852)

Strickland KC, Howitt BE, Shukla SA, Rodig S, Ritterhouse LL, Liu JF, Garber JE, Chowdhury D, Wu CJ, D'Andrea AD, et al. 2016 Association and prognostic significance of BRCA1/2-mutation status with neoantigen load, number of tumor-infiltrating lymphocytes and expression of PD-1/PD-L1 in high grade serous ovarian cancer. Oncotarget 7 13587-13598. (doi:10.18632/oncotarget.7277)

Sy SMH, Huen MSY \& Chen J 2009 PALB2 is an integral component of the BRCA complex required for homologous recombination repair. PNAS 106 7155-7160. (doi:10.1073/pnas.0811159106)

Szabo C, Masiello A, Ryan JF \& Brody LC 2000 The breast cancer information core: database design, structure, and scope. Human Mutation 16 123-131. (doi:10.1002/1098-1004(200008)16:2<123::aidhumu4>3.0.co;2-y)

Takata M, Sasaki MS, Sonoda E, Morrison C, Hashimoto M, Utsumi H, Yamaguchi-Iwai Y, Shinohara A \& Takeda S 1998 Homologous recombination and non-homologous end-joining pathways of DNA double-strand break repair have overlapping roles in the maintenance of chromosomal integrity in vertebrate cells. $E M B O$ Journal 17 5497-5508. (doi:10.1093/emboj/17.18.5497)

Takata M, Sasaki MS, Sonoda E, Fukushima T, Morrison C, Albala JS, Swagemakers SM, Kanaar R, Thompson LH \& Takeda S 2000 The Rad51 paralog Rad51B promotes homologous recombinational repair. Molecular and Cellular Biology 20 6476-6482. (doi:10.1128/ MCB.20.17.6476-6482.2000)

Takata M, Sasaki MS, Tachiiri S, Fukushima T, Sonoda E, Schild D, Thompson LH \& Takeda S 2001 Chromosome instability and defective recombinational repair in knockout mutants of the five Rad51 paralogs. Molecular and Cellular Biology $212858-2866$. (doi:10.1128/MCB.21.8.2858-2866.2001)

Takata M, Tachiiri S, Fujimori A, Thompson LH, Miki Y, Hiraoka M, Takeda S \& Yamazoe M 2002 Conserved domains in the chicken homologue of BRCA2. Oncogene 21 1130-1134. (doi:10.1038/sj. onc.1205168)

Taylor MRG, Špírek M, Chaurasiya KR, Ward JD, Carzaniga R, Yu X, Egelman EH, Collinson LM, Rueda D, Krejci L, et al. 2015 Rad51 paralogs remodel pre-synaptic Rad51 filaments to stimulate homologous recombination. Cell 162 271-286. (doi:10.1016/ j.cell.2015.06.015)

Thompson ER, Doyle MA, Ryland GL, Rowley SM, Choong DYH, Tothill RW, Thorne H, kConFab, Barnes DR, Li J, et al. 2012 Exome sequencing identifies rare deleterious mutations in DNA repair genes FANCC and BLM as potential breast cancer susceptibility alleles. PLoS Genetics 8 e1002894. (doi:10.1371/journal.pgen.1002894)

Thorslund T, Mcilwraith MJ, Compton SA, Lekomtsev S, Petronczki M, Griffith JD \& West SC 2010 The breast cancer tumor suppressor BRCA2 promotes the specific targeting of RAD51 to single-stranded DNA. Nature Structural \& Molecular Biology 17 1263-1265. (doi:10.1038/nsmb.1905)

Tian Y, Paramasivam M, Ghosal G, Chen D, Shen X, Huang Y, Akhter S, Legerski R, Chen J, Seidman MM, et al. 2015 UHRF1 Contributes to DNA damage repair as a lesion recognition factor and nuclease scaffold. Cell Reports 10 1957-1966. (doi:10.1016/j.celrep.2015.03.038)

Torre LA, Bray F, Siegel RL \& Ferlay J 2015 Global cancer statistics, 2012. CA: A Cancer Journal for Clinicians 65 87-108. (doi:10.3322/caac.21262)

Trego KS, Groesser T, Davalos AR, Parplys AC, Zhao W, Nelson MR, Hlaing A, Shih B, Rydberg B, Pluth JM, et al. 2016 Non-catalytic roles for XPG with BRCA1 and BRCA2 in homologous recombination and genome stability. Molecular Cell 61 535-546. (doi:10.1016/j.molcel.2015.12.026) 
Tsuzuki T, Fujii Y, Sakumi K, Tominaga Y, Nakao K, Sekiguchi M, Matsushiro A, Yoshimura Y \& Morita T 1996 Targeted disruption of the Rad51 gene leads to lethality in embryonic mice. PNAS 93 6236-6240. (doi:10.1073/pnas.93.13.6236)

Unno J, Itaya A, Taoka M, Sato K, Tomida J, Sakai W, Sugasawa K, Ishiai M, Ikura T, Isobe T, et al. 2014 FANCD2 binds CtIP and regulates DNA-end resection during DNA interstrand crosslink repair. Cell Reports 7 1039-1047. (doi:10.1016/j.celrep.2014.04.005)

Vaclová T, Gómez-López G, Setién F, Bueno JMG, Macías JA, Barroso A, Urioste M, Esteller M, Benitez J \& Osorio A 2015 DNA repair capacity is impaired in healthy BRCA1 heterozygous mutation carriers. Breast Cancer Research and Treatment 152 271-282. (doi:10.1007/s10549-015-3459-3)

Vasanthakumar A, Arnovitz S, Marquez R, Lepore J, Rafidi G, Asom A, Weatherly M, Davis EM, Neistadt B, Duszynski R, et al. 2016 Brca1 deficiency causes bone marrow failure and spontaneous hematologic malignancies in mice. Blood 127 310-313. (doi:10.1182/blood-201503-635599)

Vaz F, Hanenberg H, Schuster B, Barker K, Wiek C, Erven V, Neveling K, Endt D, Kesterton I, Autore F, et al. 2010 Mutation of the RAD51C gene in a Fanconi anemia-like disorder. Nature Genetics 42 406-409. (doi:10.1038/ng.570)

Virts EL, Jankowska A, MacKay C, Glaas MF, Wiek C, Kelich SL, Lottmann N, Kennedy FM, Marchal C, Lehnert E, et al. 2015 AluY-mediated germline deletion, duplication and somatic stem cell reversion in UBE2T defines a new subtype of Fanconi anemia. Human Molecular Genetics 24 5093-5108. (doi:10.1093/hmg/ddv227)

Wagner JE, Tolar J, Levran O, Scholl T, Deffenbaugh A, Satagopan J, Ben-Porat L, Mah K, Batish SD, Kutler DI, et al. 2004 Germline mutations in BRCA2: shared genetic susceptibility to breast cancer, early onset leukemia, and Fanconi anemia. Blood 103 3226-3229. (doi:10.1182/blood-2003-09-3138)

Wang X, Andreassen PR \& D'Andrea AD 2004 Functional interaction of monoubiquitinated FANCD2 and BRCA2/FANCD1 in chromatin. Molecular and Cellular Biology 24 5850-5862. (doi:10.1128/ MCB.24.13.5850-5862.2004)

Wang AT, Kim T, Wagner JE, Conti BA, Lach FP, Huang AL, Molina H, Sanborn EM, Zierhut H, Cornes BK, et al. 2015 A dominant mutation in human RAD51 reveals its function in DNA interstrand crosslink repair independent of homologous recombination. Molecular Cell 59 478-490. (doi:10.1016/j.molcel.2015.07.009)

West SC 2003 Molecular views of recombination proteins and their control. Nature Reviews Molecular Cell Biology 4 435-445. (doi:10.1038/nrm1127)

Wiese C, Dray E, Groesser T, San Filippo J, Shi I, Collins DW, Tsai M-S, Williams GJ, Rydberg B, Sung P, et al. 2007 Promotion of homologous recombination and genomic stability by RAD51AP1 via RAD51 recombinase enhancement. Molecular Cell 28 482-490. (doi:10.1016/j.molcel.2007.08.027)

Wooster R, Bignell G, Lancaster J, Swift S, Seal S, Mangion J, Collins N, Gregory S, Gumbs C \& Micklem G 1995 Identification of the breast cancer susceptibility gene BRCA2. Nature 378 789-792. (doi:10.1038/378789a0)

Wu L \& Hickson ID 2003 The Bloom's syndrome helicase suppresses crossing over during homologous recombination. Nature $\mathbf{4 2 6}$ 870-874. (doi:10.1038/nature02253)

Wyatt HDM, Sarbajna S, Matos J \& West SC 2013 Coordinated actions of SLX1-SLX4 and MUS81-EME1 for holliday junction resolution in human cells. Molecular Cell 52 234-247. (doi:10.1016/ j.molcel.2013.08.035)
Xia B, Sheng Q, Nakanishi K, Ohashi A, Wu J, Christ N, Liu X, Jasin M, Couch FJ \& Livingston DM 2006 Control of BRCA2 cellular and clinical functions by a nuclear partner, PALB2. Molecular Cell 22 719-729. (doi:10.1016/j.molcel.2006.05.022)

Xie M-Z, Shoulkamy MI, Salem AMH, Oba S, Goda M, Nakano T \& Ide H 2016 Aldehydes with high and low toxicities inactivate cells by damaging distinct cellular targets. Mutation Research 786 41-51. (doi:10.1016/j.mrfmmm.2016.02.005)

Xu G, Chapman JR, Brandsma I, Yuan J, Mistrik M, Bouwman P, Bartkova J, Gogola E, Warmerdam D, Barazas M, et al. 2015 REV7 counteracts DNA double-strand break resection and affects PARP inhibition. Nature 521 541-544. (doi:10.1038/nature14328)

Yabe M, Yabe H, Morimoto T, Fukumura A, Ohtsubo K, Koike T, Yoshida K, Ogawa S, Ito E, Okuno Y, et al. 2016 The phenotype and clinical course of Japanese Fanconi anaemia infants is influenced by patient, but not maternal ALDH2 genotype. British Journal of Haematology [in press]. (doi:10.1111/bjh.14243)

Yamamoto K, Ishiai M, Matsushita N, Arakawa H, Lamerdin JE, Buerstedde J-M, Tanimoto M, Harada M, Thompson LH \& Takata M 2003 Fanconi anemia FANCG protein in mitigating radiation- and enzyme-induced DNA double-strand breaks by homologous recombination in vertebrate cells. Molecular and Cellular Biology 23 5421-5430. (doi:10.1128/MCB.23.15.54215430.2003)

Yamamoto K, Hirano S, Ishiai M, Morishima K, Kitao H, Namikoshi K, Kimura M, Matsushita N, Arakawa H, Buerstedde J-M, et al. 2004 Fanconi anemia protein FANCD2 promotes immunoglobulin gene conversion and DNA repair through a mechanism related to homologous recombination. Molecular and Cellular Biology 25 34-43. (doi:10.1128/MCB.25.1.34-43.2005)

Yamamoto KN, Kobayashi S, Tsuda M, Kurumizaka H, Takata M, Kono K, Jiricny J, Takeda S \& Hirota K 2011 Involvement of SLX4 in interstrand cross-link repair is regulated by the Fanconi anemia pathway. PNAS 108 6492-6496. (doi:10.1073/pnas.1018487108)

Yang H, Jeffrey PD, Miller J, Kinnucan E, Sun Y, Thoma NH, Zheng N, Chen P-L, Lee W-H \& Pavletich NP 2002 BRCA2 function in DNA binding and recombination from a BRCA2-DSS1ssDNA structure. Science 297 1837-1848. (doi:10.1126/science. 297.5588.1837)

Yonetani Y, Hochegger H, Sonoda E, Shinya S, Yoshikawa H, Takeda S \& Yamazoe M 2005 Differential and collaborative actions of Rad51 paralog proteins in cellular response to DNA damage. Nucleic Acids Research 33 4544-4552. (doi:10.1093/nar/gki766)

Zhang F, Ma J, Wu J, Ye L, Cai H, Xia B \& Yu X 2009 PALB2 links BRCA1 and BRCA2 in the DNA-damage response. Current Biology 19 524-529. (doi:10.1016/j.cub.2009.02.018)

Zhang H, Kozono DE, O'Connor KW, Vidal-Cardenas S, Rousseau A, Hamilton A, Moreau L, Gaudiano EF, Greenberger J, Bagby G, et al. 2016 TGF- $\beta$ inhibition rescues hematopoietic stem cell defects and bone marrow failure in Fanconi anemia. Cell Stem Cell 18 668-681. (doi:10.1016/j.stem.2016.03.002)

Zhao W, Vaithiyalingam S, San Filippo J, Maranon DG, Jimenez-Sainz J, Fontenay GV, Kwon Y, Leung SG, Lu L, Jensen RB, et al. 2015 Promotion of BRCA2-dependent homologous recombination by DSS1 via RPA targeting and DNA mimicry. Molecular Cell 59 176-187. (doi:10.1016/j.molcel.2015.05.032)

Zimmermann M, Lottersberger F, Buonomo SB, Sfeir A \& de Lange T 2013 53BP1 regulates DSB repair using Rif1 to control 5' end resection. Science 339 700-704. (doi:10.1126/science.1231573)

Received in final form 18 August 2016

Accepted 22 August 2016

Accepted Preprint published online 22 August 2016
C 2016 Society for Endocrinology Printed in Great Britain
Published by Bioscientifica Ltd. 